\title{
Caracterização estrutural da porção sul do Greenstone Belt de Guarinos, GO
}

\author{
Structural characterization of the south portion \\ of the Guarinos Greenstone Belt, GO
}

Alex Joaquim Choupina Andrade Silva ${ }^{1 *}$, Luiz Sérgio Amarante Simões ${ }^{2}$

RESUMO: O mapeamento geológico na porção sul do Greenstone Belt de Guarinos possibilitou a individualizaçáo das unidades litológicas, bem como a caracterizaçấo de feiçôes estruturais. As unidades reconhecidas na área são: Serra do Cotovelo (metaultramáfica); Serra Azul (metamáfica); Unidade A (associação de rochas metaultramáficas, metamáficas e psamo-pelíticas); Cabaçal (xistos carbonosos com formaçōes ferríferas e gonditos) subdividida em Ca-1, Ca-2, Ca-3 e Ca-4; Aimbé, com subunidade inferior (formaçôes ferríferas bandadas ricas em muscovita) e superior (metapelitos associados a formaçóes ferríferas); e São Patricinho (metapelitos, subordinadamente gonditos). Metassedimentos atribuídos na literatura ao "Grupo Araxá" encontram-se sobrepostos à sequência greenstone através de uma descontinuidade. Durante o mapeamento geológico, não foram identificadas feiçôes estruturais de comportamento dúctil, como milonitos, e/ou rúptil, como brechação, no contato entre o "Grupo Araxá" e os litotipos do greenstone belt de Guarinos, sugerindo que esse contato possa representar uma discordância estratigráfica e não uma falha de empurrão de baixo ângulo, como descrito na literatura. A compreensão da geometria e a superposição de estruturas permitiram caracterizar cinco eventos deformacionais abrangendo todas as unidades da sequência greenstone, $\mathrm{D}_{\mathrm{n}-2} \mathrm{e}$ $\mathrm{D}_{\mathrm{n}-1}$, que antecedem a fase principal $\left(\mathrm{D}_{\mathrm{n}}\right), \mathrm{D}_{\mathrm{n}+1} \mathrm{e} \mathrm{D}_{\mathrm{n}+2}$. As rochas apresentam condiçôes de fácies xisto verde, desde a zona da biotita, no sul, até a zona da granada, no norte da área. Os minerais que definem o auge metamórfico apresentam crescimento tardi- a pós-Dn, tanto para o greenstone quanto para os metassedimentos do "Grupo Araxá", indicando que o auge metamórfico foi coevo para as duas sequências.

PALAVRAS-CHAVE: Greenstone belt de Guarinos; geologia estrutural; fases deformacionais.
ABSTRACT: Geological mapping in the southern portion of the Guarinos Greenstone Belt in the state of Goias, Brazil, led to the characterization of structural features and recognition of the following lithostratigraphic units: Serra do Cotovelo (meta-ultramafic); Serra Azul (meta-mafic); Unit A (association of meta-ultramafic, meta-mafic, and psamo-pelitic rocks); Cabaçal (carbonaceous shales with iron formations and gondites) subdivided into Ca-1,Ca-2, Ca-3 and Ca-4; Aimbé, with lower (muscovite-rich banded iron formations) and upper (metapelites associated with iron formations) subunits; and São Patricinho (metapelites, subordinately gondites). Metasediments, referred to the "Araxa Group" in the local literature, unconformably overlie the greenstone sequence. During geological mapping, no structural feature resulting from ductile or brittle deformation (mylonite or breccia) was found at the contact between the so-called Araxa Group metasediments and the Guarinos greenstone belt lithotypes, which suggests that this contact may represent a stratigraphic unconformity and not a thrust fault, as described in the literature. On the basis of structural geometry and superposition criteria, five deformational events covering all units of the greenstone sequence have been characterized: $D_{n-2}$ and $D_{n-1}$, preceding the main phase $\left(D_{n}\right), D_{n+1}$ and $D_{n+2}$. The rocks were formed under greenschist facies conditions, from the biotite zone in the south to the garnet zone in the northern area. The minerals that define the metamorphic peak exhibit late to post-Dn growth for both the greenstone metasediments and the "Araxá Group" indicating that peak metamorphism was coeval in both sequences.

KEYWORDS: Guarinos Greenstone Belt; structural geology; deformation phases.

${ }^{1}$ Programa de Pós-Graduação em Geologia Regional, Instituto de Geociências e Ciências Exatas, Universidade Estadual Paulista “Júlio de Mesquita Filho” - UNESP, Rio Claro (SP), Brasil. E-mail: jqchoupina@hotmail.com

2Instituto de Geociências e Ciências Exatas, Universidade Estadual Paulista “Júlio de Mesquita Filho” - UNESP, Rio Claro (SP), Brasil. E-mail: lsimoes@rc.unesp.br *Autor correspondente

Manuscrito ID 29991. Recebido em: 18/06/2013. Aprovado em: 22/11/2013 


\section{INTRODUÇÃO}

A província aurífera de Crixás, Goiás, possui três faixas de sequências vulcanossedimentares de idades arqueano/paleoproterozoicas, conhecidas como greenstone belts de Crixás, Guarinos e Pilar de Goiás (Fig. 1A).

Apesar dos vários trabalhos sobre a geologia dos três greenstone belts, devido à complexidade estrutural da área, muitos aspectos ainda carecem de entendimento. Assim, trabalhos de campo em escala de detalhe tendem a trazer novas informaçóes que conduzem ao aprimoramento da cartografia geológica e, consequentemente, a novas interpretaçóes sobre a evolução geológica da região.

Este trabalho apresenta resultados de mapeamento geológico em escala 1:25.000 realizado nas rochas da porção sul do Greenstone Belt de Guarinos (Fig. 1B), que é limitado a leste e a oeste por gnaisses do Complexo Moquém e do Complexo Caiamar, respectivamente, estando o conjunto sotoposto ao de metassedimentos atribuídos ao "Grupo Araxá". A denominação "Grupo Araxá” para os metassedimentos da porção sul do Greenstone de Guarinos é mantida neste artigo devido a trabalhos de diversos autores (Danni \& Ribeiro 1978, Sabóia 1979, Ribeiro 1981, Castro \& Magalhães 1984, Danni 1988, Jost et al. 1995, Lacerda 1997, Queiroz 2000) que correlacionam essas rochas com os mica xistos da faixa Brasília. Além disso, a ausência de dados geocronológicos mais precisos não permite uma nova definição para esses metassedimentos.

São apresentados novos dados cartográficos e de geologia estrutural, com base em informaçôes obtidas em trabalhos de campo e estudos detalhados de microestruturas, que contribuem para uma nova interpretação dos eventos deformacionais do Greenstone Belt de Guarinos.

\section{GEOLOGIA REGIONAL}

$\mathrm{Na}$ porção norte do Maciço de Goiás, ocorrem os greenstones de Crixás, Guarinos e Pilar de Goiás. O Greenstone Belt de Guarinos limita-se a norte com rochas neoproterozoicas, do arco Magmático de Goiás por meio da Zona de Cisalhamento Mandinópolis (Jost et al. 2001, 2012) (Fig. 1A).

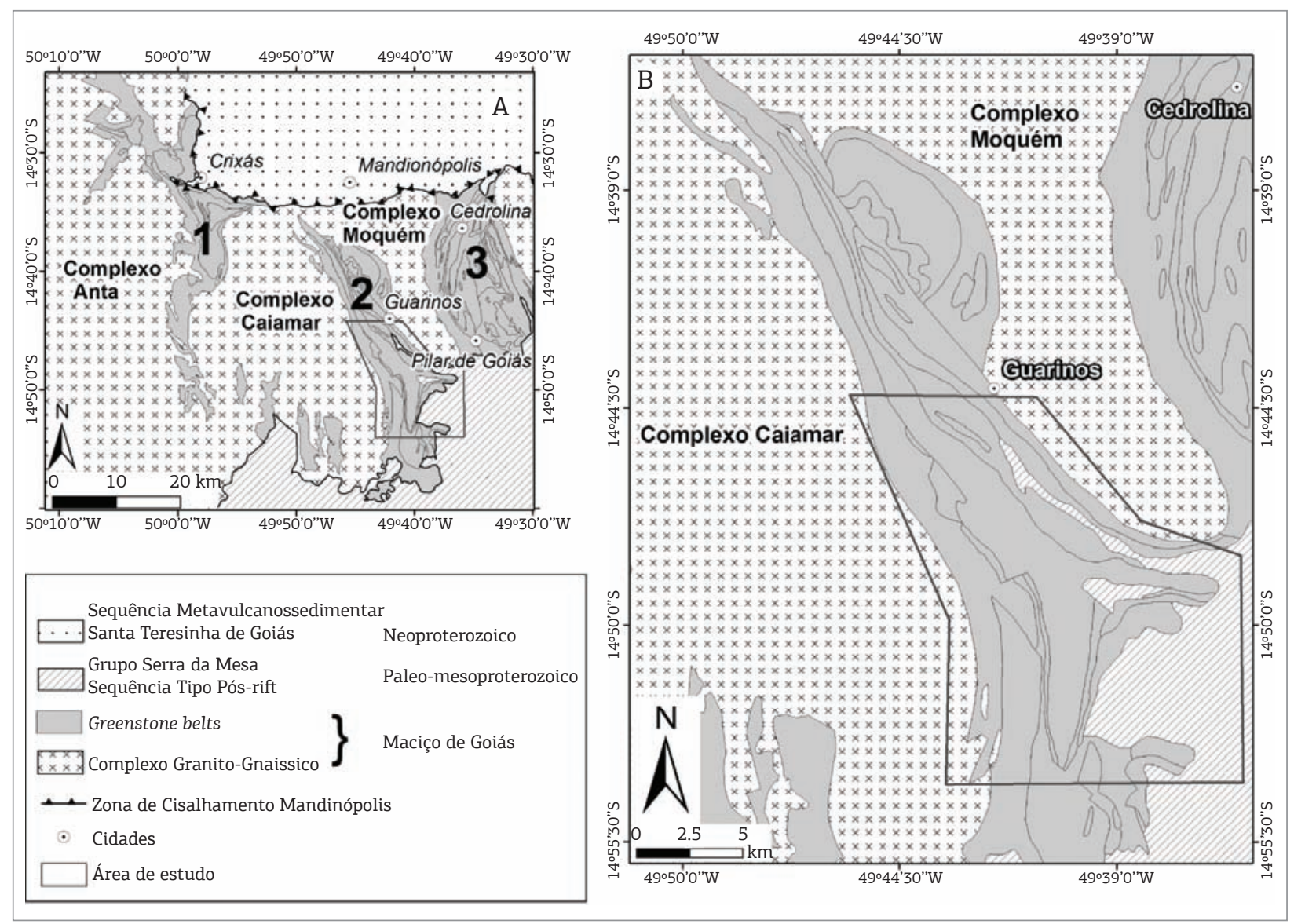

Figura 1. Área de estudo no contexto geológico da região. (A) Greenstone belts de Crixás (1), Guarinos (2) e Pilar de Goiás (3). (B) Porção sul do Greenstone de Guarinos com delimitação da área mapeada na escala 1:25.000 (Modificado de Lacerda Filho \& Frasca, 2008). 
A leste e a oeste, limita-se com os complexos Moquém e Caiamar, respectivamente, por contatos tectônicos. Na porção sul, é limitado por rochas metassedimentares da Sequência Pós-Rift (paleo-mesoproterozoica).

A estratigrafia do Greenstone Belt de Guarinos, definida por Jost e Oliveira (1991), é representada, da base para o topo, pelas formaçôes Serra do Cotovelo (metakomatiitos, serpentinitos, talco xisto e filitos carbonosos), Formaçáo Serra Azul (metabasalto, anfibolito e intercalaçôes de filitos carbonosos), Formação São Patricinho (metaturbiditos derivados de basaltos), Formação Aimbé (formação ferrífera bandada) e Formação Cabaçal (quartzo-sericita, quartzosericita-clorita filitos e filito carbonoso).

\section{SÍNTESE DAS PROPOSTAS PARA A GEOLOGIA ESTRUTURAL DO GREENSTONE BELT DE GUARINOS}

A Zona de Cisalhamento Engenho Velho divide em dois domínios o Greenstone Belt de Guarinos, tendo, assim, certa complexidade (Pulz 1995, Jost \& Fortes 2001). A zona de cisalhamento estende-se longitudinalmente na porção central do greenstone, com deslocamento direcional a oblíquo e destral.

Segundo Danni e Ribeiro (1978) e Sabóia (1979), as rochas dos greenstone belts de Guarinos e Pilar de Goiás foram afetadas por duas fases deformacionais. A primeira, $\mathrm{D}_{1}$, é marcada por uma xistosidade coincidente com o acamamento, e a fase $\mathrm{D}_{2}$, responsável pelo desenvolvimento de uma xistosidade plano-axial (Kinks), mais jovem. Danni (1988) propôs para esses greenstones belts dois eventos de deformação $\left(D_{1}\right.$ e $\left.D_{2}\right)$. Segundo o autor, essas feiçóes estruturais estâo impressas por foliaçóes plano-axiais $S_{1}$ e $S_{2}$ em duas geraçóes de dobras (isoclinais, recumbentes e apertadas), e a idade desses eventos são anteriores à ascensão dos núcleos graníticos.

Para Jost et al. (1995), as feiçóes estruturais do Greenstone Belt de Guarinos sugerem que a evoluçấo tectônica das supracrustais ocorreu em pelo menos dois estágios principais, os quais contêm evidências de uma progressão de fases iniciais de deformação dúctil para fases subsequentes de deformação rúptil. A primeira fase $\left(D_{n}\right)$ gera dobras e feiçōes associadas, $\mathrm{e}$ a segunda fase $\left(D_{n+1}\right)$ manifesta-se por falhas e dobras que se sobrepóem à primeira fase. A fase $\mathrm{D}_{\mathrm{n}}$ sucedeu após a deposição das rochas supracrustais, gerando estágio dúctil dessa deformação, caracterizando-se pela formação de uma xistosidade $\left(S_{n}\right)$, sempre disposta paralela ao bandamento composicional $\left(\mathrm{S}_{0}\right)$, o que indica uma generalizada transposiçáo de $S_{0}$ devido à formaçáo de dobras apertadas a isoclinais. Essa deformação foi responsável pela inversão estratigráfica completa das supracrustais com base nas relaçóes de topo e base determinadas a partir de estruturas primárias reliquiares da Formação Cabaçal (Jost et al. 1995). As falhas da fase $\mathrm{D}_{\mathrm{n}}$ são subparalelas a ligeiramente oblíquas à foliação metamórfica e são responsáveis pela escamação e pelas repetições estratigráficas no interior das supracrustais (Jost et al. 1995). Segundo os autores, as dobras de fase $\mathrm{D}_{\mathrm{n}+1}$ foram geradas a partir do dobramento de $\mathrm{S}_{\mathrm{n}} / / \mathrm{S}_{0}$. A geometria e a posiçâo espacial dessas dobras variam regionalmente. Em toda a regiáo, a superfície axial das dobras associadas com $\mathrm{D}_{\mathrm{n}+1}$ é uma crenulação $\left(S_{n+1}\right)$ de $S_{n}$, frequente em rochas metassedimentares detríticas, particularmente filitos carbonosos, mas rara em rochas metavulcânicas.

Para Queiroz (2000), o evento $\mathrm{D}_{\mathrm{n}-2}$ é caracterizado pelo soerguimento dos complexos granito-gnáissicos, sendo responsável pela geraçáo de $S_{n-2}$ e pela deformaçáo de $S_{n-3} / / S_{0}$. Essa deformação gerou estreitas sinformas de eixos curvilíneos. A deformação $\mathrm{D}_{\mathrm{n}-1}$ (paleoproterozoica) é dada por transporte tectônico de direção NS e vergência para N (Queiroz 2000). Nessa fase, formaram-se dobras isoclinais, apertadas e abertas com vergência para norte. Durante essa fase, não se formou uma foliação penetrativa, porém as foliaçóes de idades arqueanas $\left(\mathrm{S}_{\mathrm{n}-3} / / \mathrm{S}_{0}\right.$ e $\left.\mathrm{S}_{\mathrm{n}-2}\right)$ foram rotacionadas. Para a autora, o que mais caracteriza a fase $\mathrm{D}_{\mathrm{n}-\mathrm{s}}$ ão os deslocamentos reversos para norte, movimentos destrais e sinistrais com direçōes respectivamente N30W e N30E, movimentos oblíquos com componentes direcionais destrais e sinistrais com direçôes respectivas NW e NE. A Zona de Cisalhamento Engenho Velho, de movimento transcorrente destral segundo Queiroz (2000), é gerada na fase $\mathrm{D}_{\mathrm{n}-1}$. Para autora, o evento $\mathrm{D}_{\mathrm{n}}$ é marcado por uma clivagem crenulaçấo; já $\mathrm{D}_{\mathrm{n}+1}$ é responsável pela rotaçáo da Zona de Cisalhamento Carroça, pela deflexão da Antiforme Aimbé e das foliaçôes a norte e sul do greenstone. Jost \& Fortes (2001) apresentam modelo similar ao de Queiroz (2000), no qual uma fase $\mathrm{D}_{1}$ resulta de um evento regional de deformação e metamorfismo envolvendo os três greenstone belts, gerando uma foliação metamórfica $\left(S_{1}\right)$ paralela ao bandamento original $\left(S_{0}\right)$, indicando transposição e formação de dobras isoclinais a apertadas. Ainda nessa fase, ocorre a primeira inversão estratigráfica (Jost et al. 1995, Queiroz 2000, Jost \& Fortes 2001) nos greenstones de Crixás e Guarinos, uma vez que a estrutura de domos-e-quilhas já afeta sequências supracrustais, parcialmente invertidas (Queiroz 2000). Para os autores, a fase $\mathrm{D}_{2}$ é caracterizada pela elevação dos complexos granito-gnaisses Anta, Caiamar e Hidrolina. A fase $\mathrm{D}_{3}$ é marcada pela reorientação de $\mathrm{S}_{1}$ e $S_{0}$ no Greenstone de Guarinos, como também pelas geraçôes de falhas de empurrão, dobra em bainha, lineaçóes de estiramento e atividade magmática. $\mathrm{O}$ evento $\mathrm{D}_{4}$ resultou no redobramento de dobras $\mathrm{D}_{3}$, e a frequência de feiçóes estruturais relacionada nessa fase diminui de oeste para leste na sequência greenstone (Jost \& Fortes, 2001). 
Percebe-se que boa parte das propostas anteriores consideram que as fases de deformação principais são arqueanas e invocam o desenvolvimento da estrutura em domos-equilhas. Essas interpretaçóes não se ajustam aos dados geocronológicos mais recentes que indicam idade paleoproterozoica $(2,3 \mathrm{Ga})$ para rochas da formação Aimbé (Jost et al. 2008), enquanto os complexos gnáissicos são arqueanos (em torno de 2,7 Ga) (Queiroz et al. 2000). Além disso, a maior parte das estruturas registradas nas rochas do Greenstone Belt de Guarinos são anteriores às identificadas nas rochas do "Grupo Araxá", o que é inconsistente com os dados apresentados adiante. $\mathrm{O}$ presente trabalho mostra que praticamente todas as estruturas registradas nas rochas do greenstone belt também são observadas nas rochas do "Grupo Araxá". Assim, este artigo visa a descrever, comparar e interpretar as principais feiçóes estruturais registradas nos litotipos do greenstone belt e do "Grupo Araxá", a partir de dados levantados no mapeamento geológico.

A Tab. 1 apresenta as propostas de evoluçáo estrutural descritas pelos diferentes autores citados neste texto.

\section{UNIDADES LITOESTRATIGRÁFICAS}

A área inclui os domínios gnáissicos Moquém e Caiamar e o Greenstone Belt de Guarinos (GBG). No greenstone, foram individualizadas seis unidades litoestratigráficas, cartografadas na escala 1:25.000, procurando-se manter as denominaçóes já utilizadas na bibliografia. Uma importante falha de alto ângulo, denominada aqui de Falha Azul, segmenta longitudinalmente a Sequência Greenstone em dois conjuntos, o bloco W, onde são encontradas as rochas representativas das formaçóes Serra do Cotovelo (abaixo) e Serra Azul (acima), e o bloco E, onde ocorrem as demais unidades dessa sequência. Tal situação não permite que se identifique na região do GBG a relação estratigráfica entre as unidades dos dois blocos. No bloco E, o empilhamento encontrado, da base para o topo, é definido pelas unidades A, Cabaçal 1, 2, 3 e 4, Aimbé, São Patricinho Inferior e Superior.

Jost e Oliveira (1991) propuseram que a estratigrafia nessa porção do GBG encontra-se invertida, sendo tal interpretação adotada por outros autores (Jost et al. 1995, Resende \& Jost 1995, Queiroz 2000). Mais recentemente, Jost et al. (2012) reafirmam essa proposta, porém destacam que a única evidência dessa inversão é a feição interpretada como cone exalativo encontrada estruturalmente acima das formaçôes ferríferas (Fm. Aimbé), as quais seriam alimentadas por esses condutos.

Foge ao escopo do presente trabalho discutir a existência ou não de inversão estratigráfica, pois isso exigiria levantamento de dados em escala regional e/ou a observação de estruturas geopetálicas. Como ao longo dos trabalhos de campo não foi identificada nenhuma estrutura que permitisse de forma inequívoca indicar topo e base da sequência, considera-se que o empilhamento representa a ordenação estratigráfica original; entretanto, entende-se que não é possível descartar a hipótese de inversão.

\section{Complexos granito-gnáissicos}

Os complexos Moquém e Caiamar compreendem rochas de composição tonalítica e granodiorítica. Os litotipos possuem grão médio a grosso, são bem foliados, com plagioclásio (andesina/oligoclásio) como o principal mineral constituinte (Figs. 2A e 2C), quartzo, feldspato potássico, muscovita e biotita, além de anfibólio, epidoto, titanita e zircão como acessórios. O bandamento composicional dos gnaisses é marcado pela intercalação de bandas milimétricas de quartzo+feldspato e bandas ricas em biotita, podendo também ocorrer anfibólio. A textura dessas rochas é granoblástica (Figs. 2B e 2D) e localmente granolepidoblástica.

\section{Greenstone Belt de Guarinos}

Compreende litotipos metaultramáficos, metamáficos, metapelitos, metapsamíticos e metassedimentos químicos. As unidades individualizadas, do ponto de vista litológico, correspondem em geral às definiçóes apresentadas por Jost e Oliveira (1991) e Jost et al. (1995); por isso, apesar de ser proposta uma divisão estratigráfica distinta, as denominaçóes das unidades são mantidas, a fim de se evitar uma proliferação de nomes. Como referido anteriormente, o GBG é seccionado longitudinalmente pela Falha Azul, que separa no Bloco W as unidades Serra do Cotovelo e Serra Azul das demais que ocorrem no Bloco E. Assim, a descrição a seguir começa pelas rochas do Bloco W, seguida pelas do Bloco E.

A Formação Serra do Cotovelo está em contato, provavelmente normal, com a Formação Serra Azul, a oeste, em contato tectônico através da Falha Azul, subvertical, com as subunidades Ca-4 e Ca-3 da Formação Cabaçal e com as formaçōes Aimbé e São Patricinho, como se pode observar no mapa geológico (Fig. 3). As rochas identificadas nessa unidade são talco xisto, talco-tremolita xisto, clorita-talco xisto, serpentinito e, subordinadamente, anfibólio xisto (com actinolita e/ou tremolita). Os litotipos com maiores teores de talco e tremolita/actinolita apresentam textura nematoblástica, estrutura xistosa dada pelo alinhamento de minerais aciculares/prismáticos (tremolita/actinolita) e micáceos (talco).

O serpentinito (Fig. 4A) apresenta na matriz predominância de crisotila com opacos disseminados e, localmente, tem cristais de tremolita em agregados de acículas com até 1,5 mm de comprimento e sem orientação. No anfibólio xisto, os cristais de actinolita formam arcos poligonais, 
indicando que a foliação principal $\left(S_{n}\right)$, é uma clivagem crenulação (discutida adiante) com recristalização após dobramento. O conjunto é interpretado como um pacote de rochas metavulcânicas de composição dominantemente ultrabásica, com ocorrência subordinada de manifestaçóes básicas representadas pelos anfibólios xistos.

A Formação Serra Azul compreende anfibolitos e, com menor frequência, anfibólio xisto (Fig. 4B), lentes de talco xisto e contribuição de metassedimentos clásticos e químicos. Essa formação está em contato com o Complexo Caiamar, a oeste, e a leste com os litotipos da Formação Serra do Cotovelo. O contato entre o Complexo Caiamar e as rochas da Formaçáo Serra Azul é marcado por zona de cisalhamento de componente provavelmente direcional e que gera uma forte foliação milonítica vertical, de direção NW-SE e, às vezes, com tendência de mergulho íngreme para SW. Afastando-se do contato,

Tabela 1. Principais propostas de eventos deformacionais para o Greenstone Belt de Guarinos

\begin{tabular}{|c|c|c|c|c|c|c|c|c|}
\hline \multirow[b]{2}{*}{ 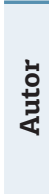 } & \multirow[b]{2}{*}{$\begin{array}{c}\text { ஜ } \\
\text { मे }\end{array}$} & \multicolumn{4}{|c|}{ Estruturas/orientações } & \multicolumn{2}{|c|}{ Dobras } & \multirow[b]{2}{*}{ 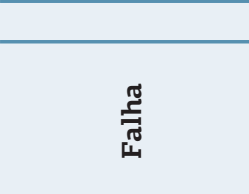 } \\
\hline & & 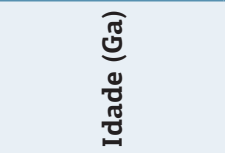 & 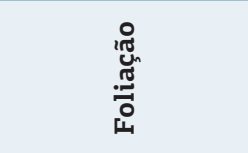 & E & $\stackrel{\Perp}{\Perp}$ & $\underset{\substack{x \\
\text { 婇 }}}{ }$ & $\stackrel{\circ}{\stackrel{2}{\rightleftarrows}}$ & \\
\hline \multirow{2}{*}{ 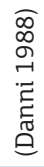 } & $\mathrm{D}_{1}$ & Arqueana & $\mathrm{S}_{1}$ & - & - & N40-60W/10 & $\begin{array}{c}\text { Isoclinal } \\
\text { assimétrica }\end{array}$ & - \\
\hline & $\mathrm{D}_{2}$ & Arqueana & $\mathrm{S}_{2}$ & - & - & N65-90W/20 & $\begin{array}{c}\text { Isoclinal } \\
\text { assimétrica }\end{array}$ & - \\
\hline \multirow{2}{*}{ 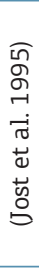 } & $\mathrm{D}_{\mathrm{n}}$ & Arqueana $\pm 2,9$ & $\begin{array}{c}\mathrm{S}_{\mathrm{n}} / / \mathrm{S}_{0=} \mathrm{N} 15 \mathrm{~W} / 35 \mathrm{SW} \\
\text { e N15W/35NE } \\
\text { (interferência de } \mathrm{D}_{\mathrm{n}+1} \text { ) }\end{array}$ & $\begin{array}{c}\text { N15W/ } \\
\text { horizontal } \\
\text { N15W/15NNW } \\
\text { N15W/15SSE }\end{array}$ & $\begin{array}{l}\text { N10W/0 } \\
\text { N10W/NW } \\
\text { N10W/SE }\end{array}$ & $\begin{array}{c}\text { N15W/0 } \\
\text { N15W/15NNW } \\
\text { N15W/15SSE }\end{array}$ & $\begin{array}{l}\text { Apertadas a } \\
\text { isoclinais }\end{array}$ & $\begin{array}{l}\text { Sinistrais oeste, } \\
\text { a leste destrais } \\
\text { N10W/30SW } \\
\text { (Inversão } \\
\text { estratigráfica) }\end{array}$ \\
\hline & $D_{n+1}$ & (?) & $\begin{array}{c}\mathrm{S}_{\mathrm{n}+1} \text { : superfície axial } \\
\text { associada a uma } \\
\text { crenulação }\end{array}$ & N15/40SW & N15/40SW & & $\begin{array}{l}\text { Normais (?), } \\
\text { apertadas e } \\
\text { inversas }\end{array}$ & $\begin{array}{c}\text { Direcionais destrais } \\
\text { nordeste N60E/90 }\end{array}$ \\
\hline \multirow{5}{*}{ 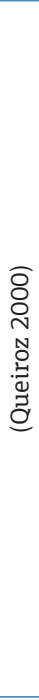 } & $D_{n-3}$ & Arqueana $\pm 2,8$ & $\begin{array}{c}\mathrm{S}_{\mathrm{n}-3} / / \mathrm{S}_{0:} \text { foliação } \\
\text { metamórfica }\end{array}$ & - & - & & $\begin{array}{c}\text { Apertadas a } \\
\text { isoclinais Domos e } \\
\text { quilha }\end{array}$ & $\begin{array}{l}\text { Inversão } \\
\text { estratigráfica }\end{array}$ \\
\hline & $D_{n-2}$ & $\begin{array}{c}\text { Arqueana } \pm 2,84 \\
\text { a Arqueana } \pm \\
2,71\end{array}$ & $S_{n-2}=S_{n-3} / / S_{0}$ & & & Curvilíneo & $\begin{array}{c}\text { Apertadas a } \\
\text { isoclinais Domos e } \\
\text { quilha, sinformes }\end{array}$ & \\
\hline & $D_{n-1}$ & Paleoproterozoica & $\begin{array}{c}S_{n-1}=N 78 W / 15 \\
S W \text { - não gerou } \\
\text { foliação penetrativa }\end{array}$ & S07E/11 & S07E/11 & $\begin{array}{l}\text { s20W/19 e } \\
\text { N37W/36 }\end{array}$ & $\begin{array}{l}\text { Raras - apertadas } \\
\text { a isoclinais }\end{array}$ & $\begin{array}{c}\text { Direcionais destrais } \\
\text { N30W e sinistrais } \\
\text { N30E, destral } \\
\text { Engenho Velho }\end{array}$ \\
\hline & $\mathrm{D}_{\mathrm{n}}$ & Neoproterozoica & $\begin{array}{c}\mathrm{S}_{\mathrm{n}}=\mathrm{N} 40 \mathrm{~W} / 23 \mathrm{SW}, \\
\text { anastomosada e } \\
\text { milonítica }\end{array}$ & N69W/18 & N69W/18 & - & $\begin{array}{l}\text { Centimétricas } \\
\text { a decimétricas, } \\
\text { apertadas a } \\
\text { isoclinais }\end{array}$ & $\begin{array}{c}\text { Desenvolvimento } \\
\text { de rampas } \\
\text { frontais, laterais e } \\
\text { oblíquas (intrusão } \\
\text { Trondhjemito Santo } \\
\text { Antônio). }\end{array}$ \\
\hline & $D_{n+1}$ & Neoproterozoica & $\begin{array}{c}\mathrm{S}_{\mathrm{n}+1:} \text { clivagem de } \\
\text { crenulação, foliação } \\
\text { mal desenvolvida } \\
\mathrm{N} 26 \mathrm{~W} / 53 \mathrm{SW} \text { e } \\
\mathrm{N} 22 \mathrm{~W} / 30 \mathrm{SW}\end{array}$ & - & - & - & $\begin{array}{l}\text { Abertas a suaves e } \\
\text { menos frequentes } \\
\text { que as } D_{n}\end{array}$ & $\begin{array}{c}\text { Direcionais destrais, } \\
\text { NS e sinistrais } \\
\text { N50W }\end{array}$ \\
\hline \multirow{4}{*}{ 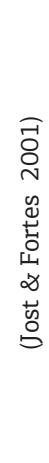 } & $\mathrm{D}_{1}$ & Arqueana & $\mathrm{S}_{1} / / \mathrm{S}_{0}$ & - & - & - & $\begin{array}{l}\text { Isoclinais a } \\
\text { apertada }\end{array}$ & $\begin{array}{c}\text { Inversão } \\
\text { estratigráfica }\end{array}$ \\
\hline & $\mathrm{D}_{2}$ & & $\begin{array}{l}\text { Eventos polifásicos } \\
\text { durante a ascensão } \\
\text { dos complexos } \\
\text { granito-gnáissicos }\end{array}$ & - & - & - & & $\begin{array}{l}\text { Ascensão dos } \\
\text { complexos granito- } \\
\text { gnáissicos }\end{array}$ \\
\hline & $\mathrm{D}_{3}$ & Paleoproterozoica & Reorientação $S_{1} / / S_{0}$ & & & & Bainha & $\begin{array}{c}\text { Empurrão e } \\
\text { direcionais }\end{array}$ \\
\hline & $\mathrm{D}_{4}$ & Neoproterozoico & - & - & - & - & $\begin{array}{l}\text { Redobramento } \\
\text { de dobras } \mathrm{D}_{3} \text {, } \\
\text { isoclinais }\end{array}$ & $\begin{array}{c}\text { Deformação } \\
\text { decrescente para } \\
\text { leste, trend de } \\
\text { cisalhamento SSE, } \\
\text { vergência para leste, } \\
\text { falhas de empurrão }\end{array}$ \\
\hline
\end{tabular}

Lm: lineação mineral; Le: lineação de estiramento. 
os litotipos do Complexo Caiamar exibem uma conspícua foliação de baixo ângulo $\left(30^{\circ}-40^{\circ}\right.$ para $\left.\mathrm{SW}\right)$ marcada por biotita, plagioclásio e muscovita. Os metassedimentos químicos (metacherts) ocorrem como intercalações nas rochas metabásicas, possuem textura granular com alternância entre as diferentes granulaçóes e possuem coloração bege, amarelada e porçóes esbranquiçadas.

No Bloco E, identificou-se uma sequência predominantemente metassedimentar, mas com contribuição ocasional de rochas metavulcânicas. A unidade inferior desse pacote é aqui denominada informalmente de Unidade A, sendo seguida pelas unidades Cabaçal 1, 2, 3, 4. Acima destas seguem as Formaçóes Aimbé e São Patricinho.

Os litotipos da Unidade A são talco xisto (Fig. 4C), xisto carbonoso intercalado com gondito, associação de biotitaclorita xisto/muscovita xisto e anfibolito. Esse conjunto de rochas apresenta direção NW-SE, estando em contato por falha direcional com o Complexo Moquém, a leste, contato estratigráfico com a subunidade Ca-1 da Formação Cabaçal e por discordância com os litotipos do "Grupo Araxá".

A Formação Cabaçal é composta em sua maior parte por xisto carbonoso constituído por muscovita, biotita, quartzo, material carbonoso e granada (espessartita), com intercalaçóes de gonditos (Fig. 4D) e BIF's (Fig. 4E). Outro litotipo observado é quartzo-muscovita xisto, com clorita, granada, biotita e magnetita, comumente com intercalações de quartzito e mica xisto. Os gonditos apresentam em geral mineralogia composta por espessartita e quartzo e ocorrem comumente intercalados no xisto carbonoso, formando camadas com espessuras centimétricas a decamétricas. Quando alterados, apresentam moldes semicirculares identificando os cristais de granada. A Formação Cabaçal é subdividida da base para o topo em quatro subunidades, Ca-1, Ca-2, Ca-3, e Ca-4, em função da proporção entre
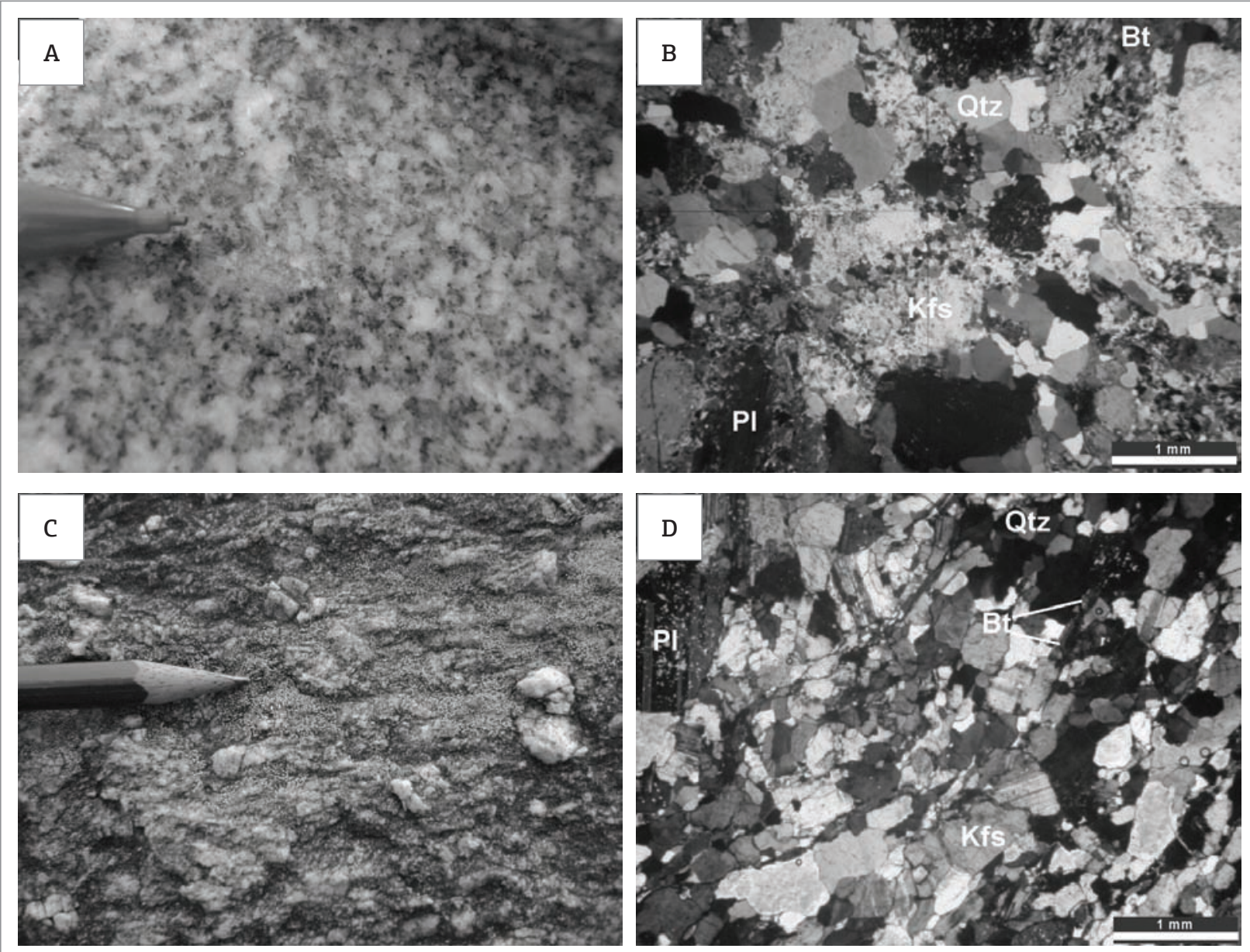

Pl: Plagioclásio; Bt: Biotita; Kfs: feldspato potássico; Qtz: Quartzo (Kretz 1983).

Figura 2. (A) Amostra de biotita-gnaisse do Complexo Caiamar. (B) Fotomicrografia de gnaisse de composição granodiorítica, granulação média, textura granoblástica. Cristais de plagioclásio mostram-se parcialmente saussuritizados. (C) Afloramento de muscovita-biotita gnaisse do Complexo Moquém. (D) Fotomicrografia de muscovita-biotita gnaisse do Complexo Moquém. 
xisto carbonoso e os demais litotipos. A subunidade $\mathrm{Ca}-4$ ocorre na porção oeste, em contato por falha com a Formação Serra do Cotovelo e normal com a Formação Aimbé. A Ca-4 é composta por xisto carbonoso, intercalado com camadas decimétricas a decamétricas de metachert, gonditos e BIF's. Esses BIF's, que caracterizam a subunidade, ocorrem como camadas de aproximadamente $50 \mathrm{~m}$ de espessura e sustentam cristas de serra ou ocorrem como corpos lenticulares (espessura decimétrica a métrica). Os litotipos do conjunto $\mathrm{Ca}-4$ não possuem continuidade para norte, pois as camadas são truncadas pelo plano de falha que divide a sequência máfica/ultramáfica do restante do empilhamento, e para sul são truncados por rochas da Formação Aimbé. A transição de Ca-4 para a subunidade Ca-3 é marcada pela diminuição da frequência e espessura das camadas de BIF's. A subunidade Ca-3 ocorre em uma faixa N-S, com maior representatividade nas porçóes norte e sul da área, pois na porção central ocorre um adelgaçamento da unidade, provavelmente devido às deformaçóes. Essa subunidade difere das demais por ser constituída essencialmente por xisto carbonoso, embora muscovita xistos, gonditos, formaçóes ferríferas e anfibólio xisto (às vezes ricos em clorita) ocorram em pequenas quantidades. $\mathrm{O}$ muscovita xisto e o anfibólio xisto concentram-se na porção sul e ocorrem como lentes de aproximadamente $20-30 \mathrm{~m}$ de espessura intercaladas ao xisto carbonoso. A unidade $\mathrm{Ca}-2$ é composta por xisto carbonoso, muscovita-quartzo xisto e abundantes rochas de sedimentação química do tipo gondito e metachert. A subunidade Ca-1 ocorre na porção nordeste da área estudada em uma faixa de direção NW-SE, fazendo contato a E com as rochas da Unidade A e a oeste com a Ca2. Para sul, esse contato está recoberto pelos metassedimentos do "Grupo Araxá". A diversidade de litotipos varia de SE para NW a sul, ocorrem clorita-muscovita-quartzo xisto e biotita xisto na porção central e clorita xisto e clorita-anfibólio-quartzo xisto na parte norte; esses litotipos ocorrem intercalados a xisto carbonoso, além de formações ferríferas e lentes de talco xisto ao longo de toda a faixa.

A Formação Aimbé é caracterizada pela ocorrência de uma formação ferrífera bandada de composição incomum, constituída essencialmente por muscovita e magnetita (Fig. 4G). Além da formaçáo ferrífera, encontra-se na porçáo sudeste da área um pacote de cloritoide-muscovita xisto sobreposto às formaçôes ferríferas. Assim, a porção inferior (PAff) é formada por formaçôes ferríferas com hematita (incluindo especularita) e magnetita, com matriz

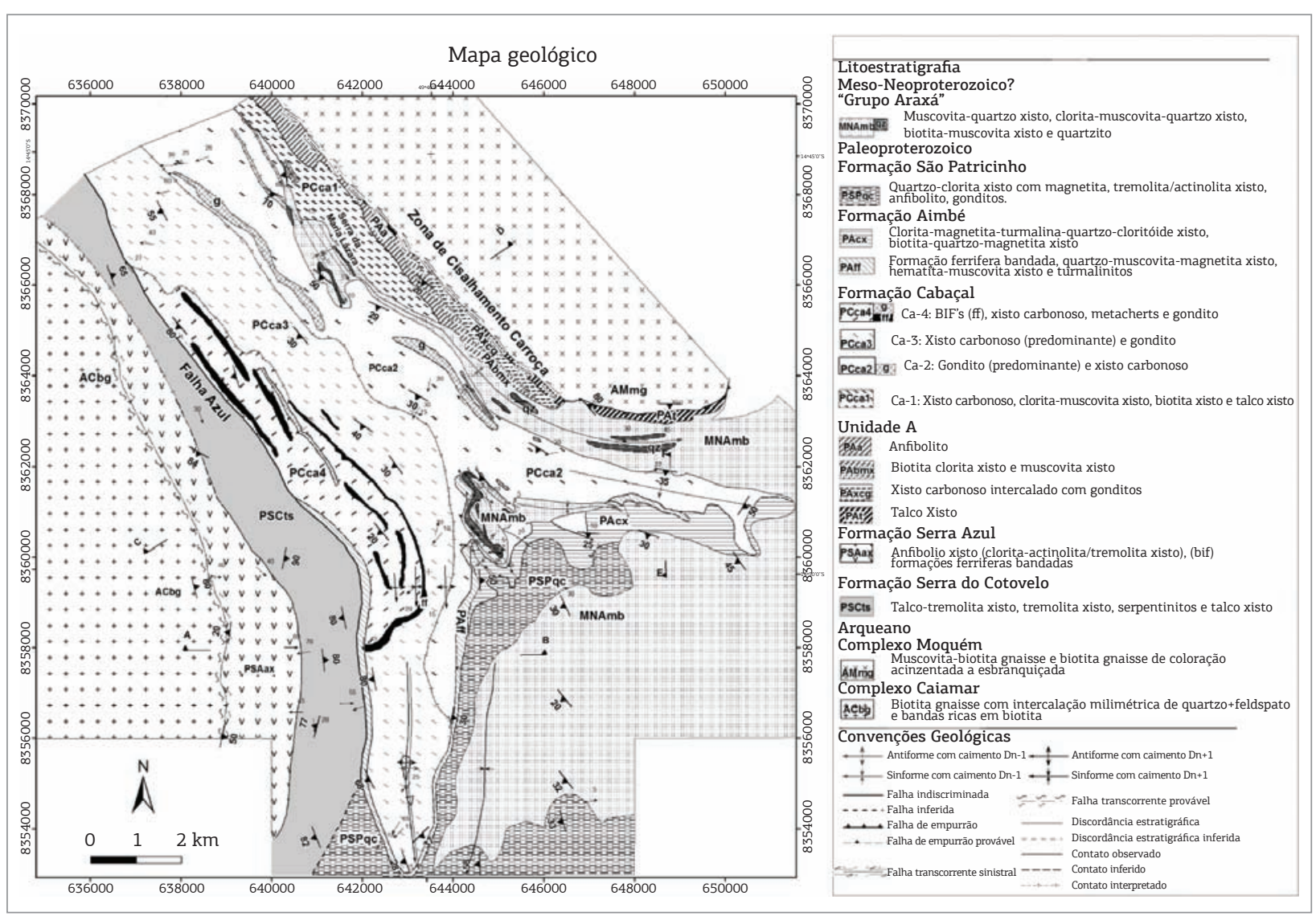

Figura 3. Mapa geológico da área situada na porção sul do Greenstone Belt de Guarinos. 

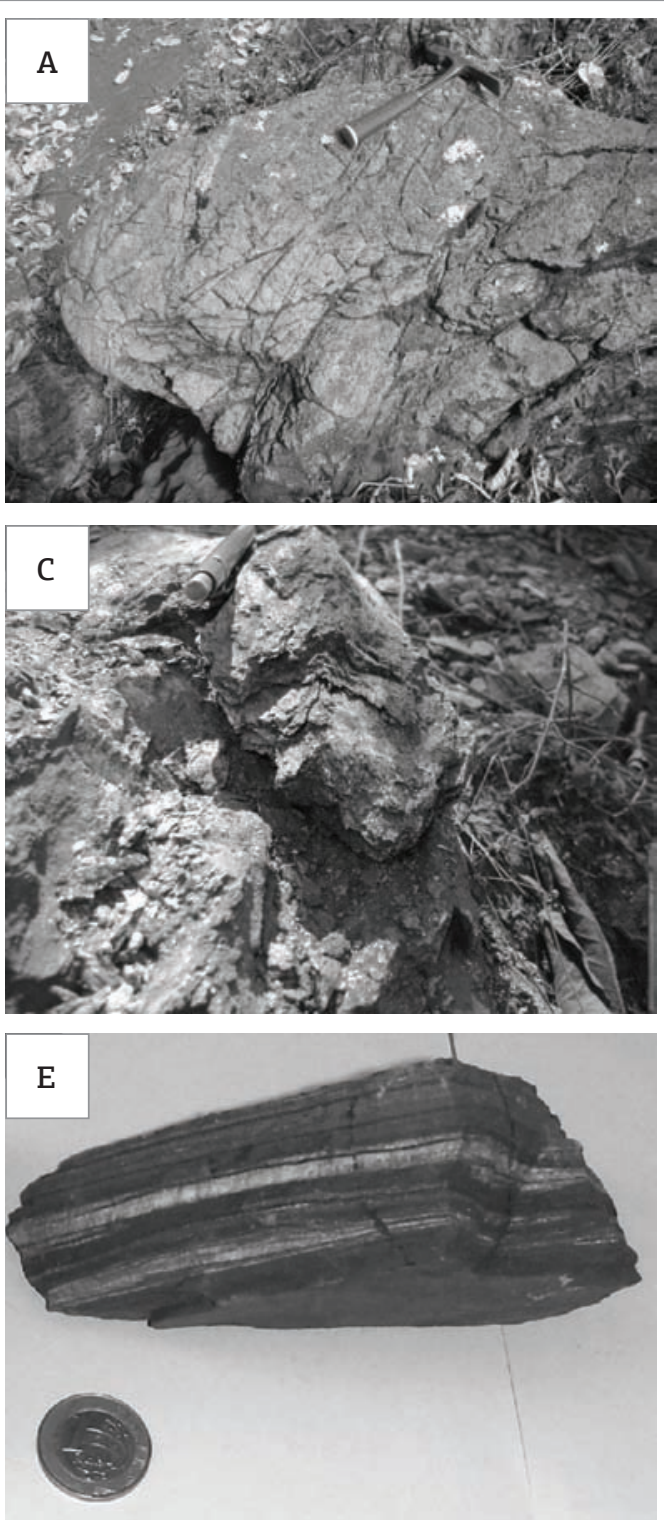
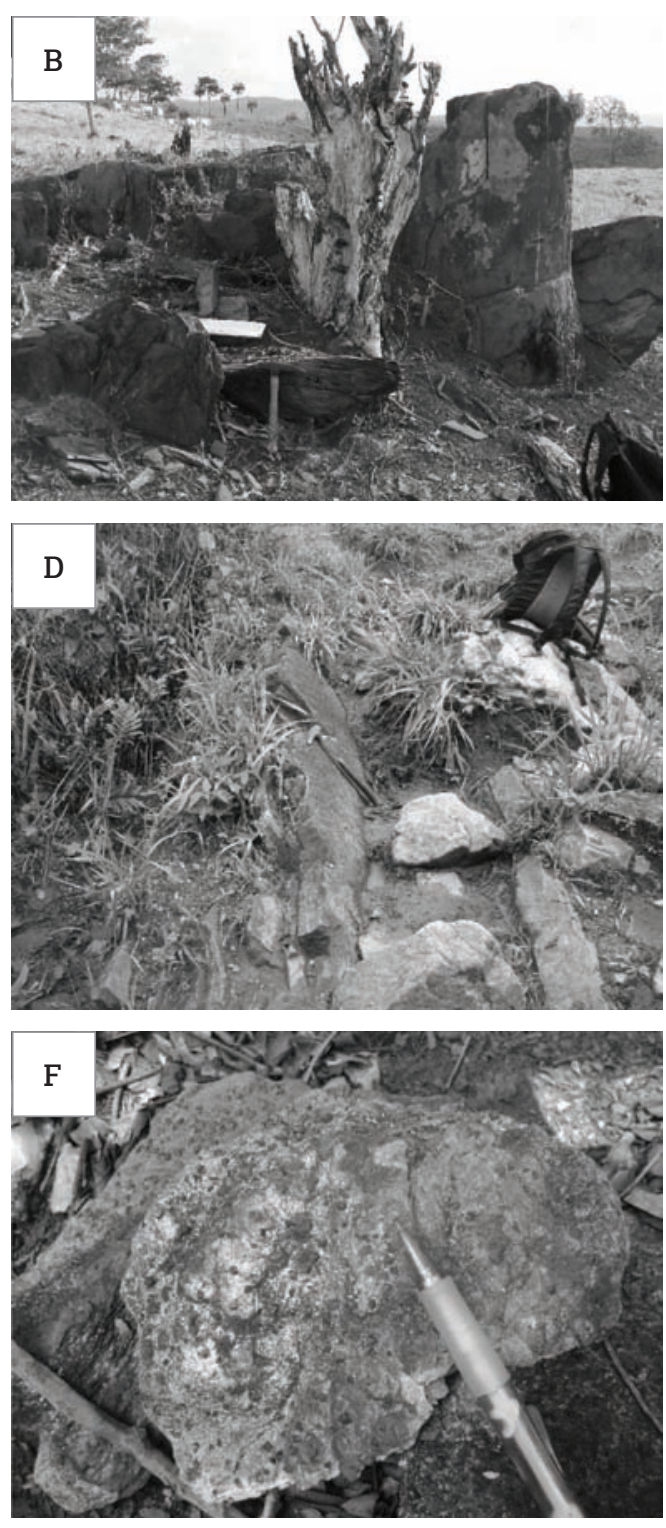

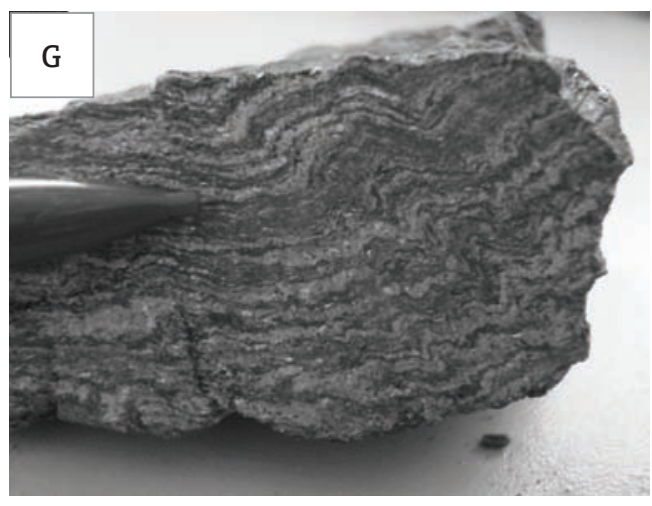

Figura 4. Fotografias de afloramentos e amostras de mão dos litotipos do greenstone. (A) Serpentinito da Formação Serra do Cotovelo (Ponto AJM-575). (B) Afloramento de anfibólio xisto da Formação Serra Azul (GU-3-3). (C) Afloramento de talco xisto, um dos litotipos da Unidade A. (D) Afloramento da subunidade Ca-2, expondo camadas centimétricas de gondito (AJM-318). (E) Amostra de formação ferrífera bandada, litotipo da subunidade Ca-4(AJM-81). (F) Amostra de muscovita-clorita xisto com porfiroblastos de magnetita, da Fm. São Patricinho. Os cristais de magnetita apresentam tamanhos milimétricos a centimétricos (AJM-459). (G) Amostra de muscovita-magnetita xisto, bandas de muscovita (clara) e bandas de magnetita com muscovita (cinza) da Formação Aimbé inferior (AJM-209). 
de muscovita e quartzo. A porção superior (PAcx) é constituída por clorita-magnetita-turmalina-quartzo-cloritoide xisto, clorita-quartzo-magnetita xisto e quartzo-magnetitaturmalina-cloritoide xisto.

A Formação São Patricinho abrange uma área caracterizada por um solo vermelho em relevo suavizado, e os litotipos descritos correspondem àqueles preservados do processo de alteração intempérica; portanto, a caracterização do conjunto litológico dessa unidade está incompleta. Os litotipos identificados compreendem rochas heterogêneas, tais como quartzo-clorita xisto com magnetita (Fig. 4F), tremolita/actinolita xisto, anfibolito e gondito. Os xistos apresentam variadas porçôes de muscovita, clorita e quartzo, subordinadamente sericita, biotita, magnetita e, por vezes, plagioclásio e turmalina. Tais rochas possuem coloração verde escura e cinza metálica quando sãs e laranja-avermelhada quando intemperizadas.

A proposta de subdivisão estratigráfica e a cartografia geológica aqui apresentadas diferem, em parte, da recente proposta de Jost et al. (2012), embora esses autores também advoguem a subdivisão da Formação Cabaçal. As principais diferenças entre as duas propostas são:

1) a unidade que denominamos de $\mathrm{Ca}-1$, no mapa dos referidos autores é apresentada como Formação Serra Azul. Embora ocorram alguns anfibolitos nesse local, os filitos carbonosos são abundantes; por isso, entendemos que atribuir Ca-1 para essas rochas da Formação Cabaçal identifica certa peculiaridade;

2) as unidades denominadas aqui de $\mathrm{Ca}-2$ e Ca-3 correspondem aproximadamente à unidade inferior desses autores;

3) a unidade $\mathrm{Ca}-4$, delimitada no presente trabalho, não possui boa correlação com aquelas propostas pelos referidos autores, mostrando superposição geográfica parcial com as quatro unidades de Jost et al. 2012. Devido ao bom controle de campo obtido por meio do mapeamento da continuidade de camadas de formaçooes ferríferas, entendemos que nossa proposta representa a configuração cartográfica mais adequada para essa localidade.

4) os referidos autores descrevem uma unidade intermediária que contém camadas com barita e que passam lateralmente a formaçóes ferríferas e gondito, possivelmente correspondendo à base da nossa unidade $\mathrm{Ca}-4$, porém não reconhecemos as ocorrências de barita.

\section{"Grupo Araxá”}

O nome é mantido neste trabalho devido a trabalhos de diversos autores (Danni \& Ribeiro 1978, Sabóia 1979, Ribeiro 1981, Castro e Magalhães 1984, Danni 1988, Jost et al. 1995, Lacerda 1997, Queiroz 2000, Jost et al. 2012) que correlacionam essas rochas com os mica xistos da Faixa Brasília. Entretanto, entende-se que é possível que os metassedimentos mapeados representem uma outra unidade litoestratigráfica. A ausência de textura milonítica típica e/ou de equivalentes de caráter rúptil, como brechação, sugere que o contato dessas rochas com a sequência greenstone belt pode ser interpretado como uma discordância. Entretanto, não se pode descartar a hipótese de que tenha havido uma superfície de cavalgamento cujas feiçóes miloníticas tenham sido apagadas pela recristalização tardi- $\mathrm{D}_{\mathrm{n}}$ sofrida por essas rochas.

Os litotipos são metassedimentos representados, essencialmente, por metapelitos, incluindo muscovita-quartzo xisto (Fig. 5A), clorita-quartzo-muscovita xisto e biotita-clorita-muscovita-quartzo xisto, por vezes com magnetita. Menos comumente, lentes de quartzito (Fig. 5B) e, muito raramente, intercalaçóes métricas de xisto carbonoso.

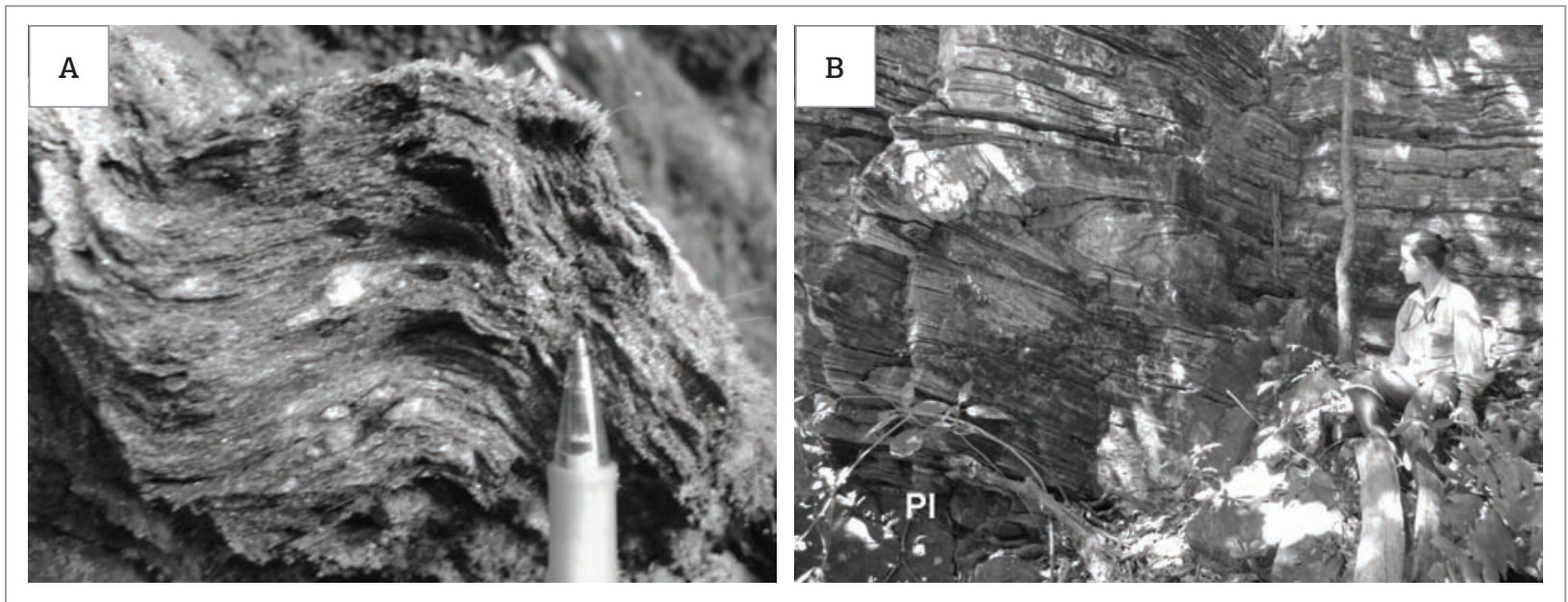

Figura 5. Fotografias de afloramentos do "Grupo Araxá". (A) Afloramento de clorita-muscovita-quartzo xisto do "Grupo Araxá" (AJM-153). (B) Quartzito do "Grupo Araxá" (AJM-416) - ocorre como lentes no pacote mais expressivo (biotita-muscovita xisto). 


\section{GEOLOGIA ESTRUTURAL}

O GBG apresenta feições estruturais que caracterizam processos de deformação predominantemente dúcteis, porém com estruturas rúpteis associadas. A análise detalhada das estruturas de macro, meso e microescalas, baseada principalmente em critérios de superposição, permite caracterizar a existência de cinco fases deformacionais $\left(\mathrm{D}_{\mathrm{n}-2}, \mathrm{D}_{\mathrm{n}-1}, \mathrm{D}_{\mathrm{n}}, \mathrm{D}_{\mathrm{n}+1}\right.$ e $\left.\mathrm{D}_{\mathrm{n}+2}\right)$. São reconhecidas três grandes descontinuidades tectônicas pós- $\mathrm{D}_{\mathrm{n}}$, que afetam o plano da foliação $S_{\mathrm{n}}$. A Zona de Cisalhamento Carroça (Fig. 3) separa as rochas metavulcanossedimentares dos gnaisses do Complexo Moquém; outra, aqui denominada de Falha Azul, ocorre adjacente a Serra Azul, limita os litotipos das formaçóes Serra do Cotovelo e Serra Azul das outras unidades do greenstone. A terceira, cuja relação temporal com a fase $\mathrm{D}_{\mathrm{n}}$ ainda não foi estabelecida, situa-se no extremo oeste da área, limitando os gnaisses do Complexo Caiamar com os litotipos da Formação Serra Azul.

A foliaçáo $S_{n}$ é uma xistosidade, por vezes correspondendo a uma clivagem de crenulaçáo, presente nas rochas metavulcanossedimentares e no "Grupo Araxá”. Por estar presente em praticamente todos os afloramentos, serve como balizador para idade relativa das demais estruturas encontradas na área, que podem ser definidas como pré-, sin- e pós- $\mathrm{D}_{\mathrm{n}}$ (Fig. 6). As deformações pré- $\mathrm{D}_{\mathrm{n}}$ são identificadas como $\mathrm{D}_{\mathrm{n}-2}$ e $\mathrm{D}_{\mathrm{n}-1}$ e as pós-Dn $\left(\mathrm{D}_{\mathrm{n}+1}\right.$ e $\left.\mathrm{D}_{\mathrm{n}+2}\right)$ afetam a foliação principal por dobras e/ou falhas. Em geral, os critérios de superposição para caracterização de fases deformacionais são relativamente simples; entretanto, a caracterização e distinção das fases $\mathrm{D}_{\mathrm{n}-1}$ e $\mathrm{D}_{\mathrm{n}-2}$ é mais complexa. Estas puderam ser definidas devido à existência de dobras de comprimento de onda hectométrico relacionadas à fase $\mathrm{D}_{\mathrm{n}-1}$ (por exemplo, as dobras na região da Serra Maria Lázara e as na porção central da área) (Fig. 3). O mapeamento das zonas de charneira dessas dobras indica que, em geral, não desenvolvem foliação plano-axial, e tanto na charneira quanto nos flancos observa-se a foliação $S_{n}$ afetando uma foliação mais antiga bem marcada por muscovita e opacos. O plano axial dessas dobras é subvertical, enquanto a foliação $S_{n}$ apresenta baixo ângulo de mergulho, com atitude aproximadamente constante, cortando os dois flancos das dobras. Tal situação indica que: (1) a dobra é mais antiga do que $S_{n}$; (2) existe uma foliação tectônica afetada por essa dobra. Então, essa foliação tem que ser atribuída a uma fase $D_{n-2}$, e a dobra, a $D_{n-1}$.

\section{Fases Pré-Dn}

A fase $\mathrm{D}_{\mathrm{n}-2}$ gera a foliação mais antiga $\mathrm{S}_{\mathrm{n}-2}$ e está paralela ao bandamento composicional dos metassedimentos, interpretado como representante do acamamento primário $\left(\mathrm{S}_{0}\right)$. Sua distinção em afloramento é difícil devido à transposição relacionada ao desenvolvimento da foliaçáo $S_{n}$. $S_{n-2}$ fica evidente em dobras da fase $\mathrm{D}_{\mathrm{n}-1}$ e $\mathrm{D}_{\mathrm{n}}$, onde, no primeiro evento, a posição do plano axial dessas dobras faz ângulo com a foliação dobrada, e no segundo, a envoltória do acamamento $S_{0}$ em posição subvertical é cortado por uma superfície axial de baixo ângulo de dobras da fase principal, permitindo, assim, uma distinção entres essas estruturas (Fig. 7A). Em escala microscópica, a $\mathrm{S}_{\mathrm{n}-2}$ é identificada em microdobras $\mathrm{D}_{\mathrm{n}}$, marcada por cristais de muscovita, que formam arco poligonal devido à rescristalização tardi- $\mathrm{D}_{\mathrm{n}}$ (Fig. 7B).

A fase $\mathrm{D}_{\mathrm{n}-1}$ é caracterizada por dobras delineadas por $\mathrm{S}_{0} / / \mathrm{S}_{\mathrm{n}-2}$, tanto na sequência greenstone como nas rochas do "Grupo Araxá". Essa deformação é responsável pela geração das grandes estruturas dobradas na área, como Antiforme Aimbé, com eixo N-S, dobras hectométricas na porção central, com eixos para SSE, e a antiforma, a leste, desenhada pelo contato basal do "Grupo Araxá", com eixo de caimento suave para E. Na porção norte da área, as rochas do "Grupo Araxá" desenham uma estrutura sinformal, acompanhada de um par antiformal/sinformal a oeste (Fig. 3). São dobras da fase $\mathrm{D}_{\mathrm{n}-1}$, com planos axiais subverticais e eixos de direçáo $145^{\circ}$, com caimento geral para SE. Para sul, essa estrutura sofre uma inflexão onde o eixo, com caimento suave, passa progressivamente para a direçáo E-W. Interpreta-se que esta curvatura do eixo pode estar relacionada a esforços compressivos gerados nas fases pós- $\mathrm{D}_{\mathrm{n}}$.

\section{Fase $\mathrm{D}_{\mathrm{n}}$}

A Fase $D_{n}$ afetou as rochas do GBG e do "Grupo Araxá", gerando a foliação principal (Sn). A deformação também gerou dobras, lineaçôes de crenulação e mineral, sendo esta última estrutura de difícil visualização nos afloramentos devido à recristalização tardi- $\mathrm{D}_{\mathrm{n}}$, que mascara a feiçáo linear. A foliação Sn nos metapelitos é uma xistosidade ou, menos frequentemente, clivagem de crenulação, marcada pela orientação de cristais de mica, anfibólio, quartzo, feldspato e grafita. Nas rochas metabásicas/ultrabásicas das formaçóes Serra Azul e Serra do Cotovelo a xistosidade é marcada por cristais de actinolita, tremolita e talco formando texturas lepidonematoblásticas.

Devido à complexidade estrutural registrada nos litotipos do greenstone belt e nos metassedimentos do Grupo Araxá, definiram-se 5 domínios estruturais a partir da orientação da foliação principal $\left(\mathrm{S}_{\mathrm{n}}\right)$ (Fig. 8). Essa compartimentação visa ao melhor entendimento da geometria das estruturas das diferentes fases e de suas variações ao longo da área.

As orientaçôes preferenciais de Sn obtidas através do estereogramas de frequência (Fig. 8) nos domínios 1, 2, 3, 4 e 5 são respectivamente: 234/35 e 224/32 (Fig. 8A); 190/38 e 196/33 (Fig. 8B); 234/33, 128/28 e 253/39 (Fig. 8C); 250/83 e 76,82 (Fig. 8D); 223/54 (Fig. 8E). A lineação mineral é marcada por cristais de muscovita e de anfibólio. 


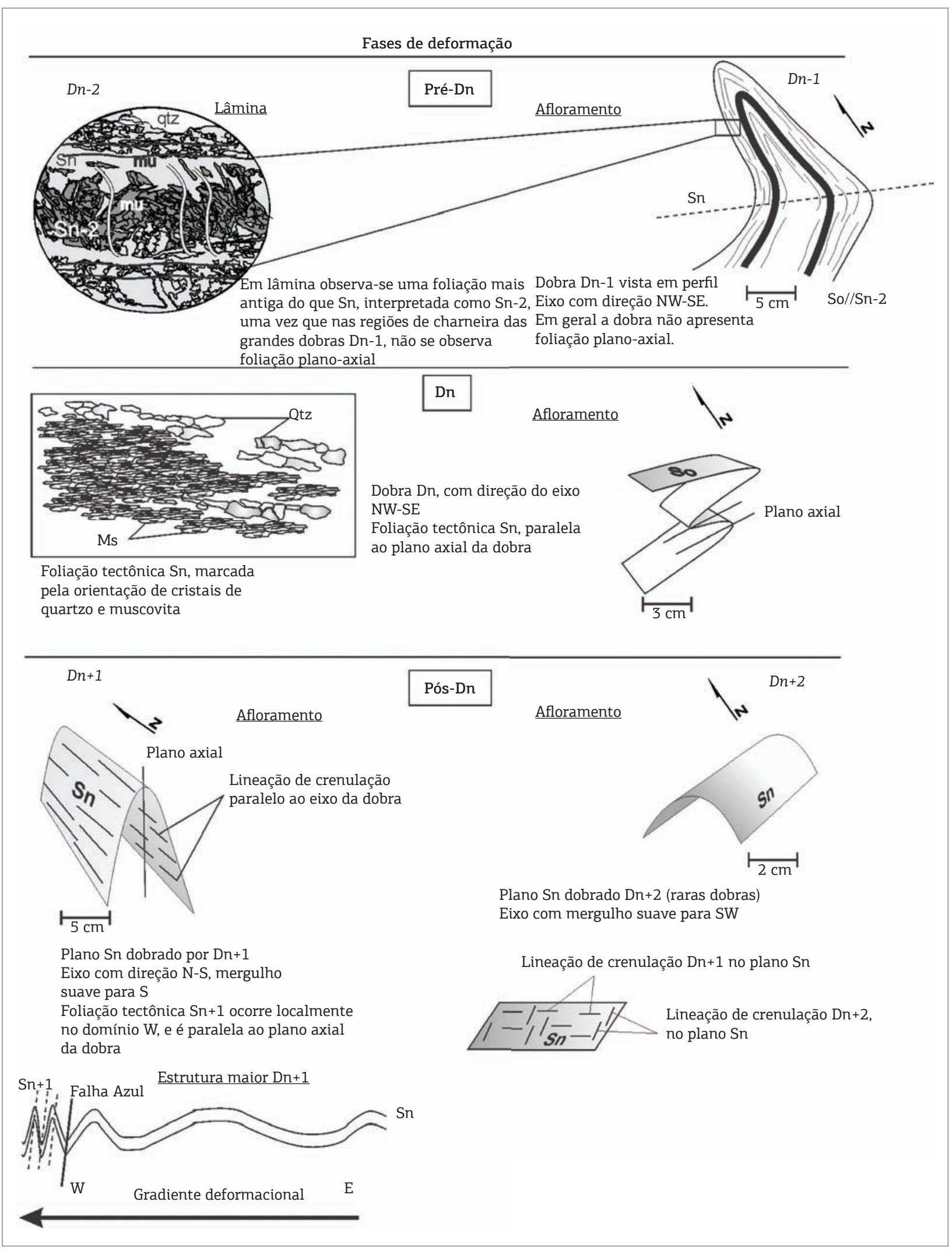

Figura 6. Figura esquemática das fases deformacionais interpretadas para porção sul do Greenstone Belt de Guarinos. A foliação $S_{n}$ é o plano marcador das estruturas pré- e pós- $D_{n}$. $S_{n}$ perturba as fases antigas e é afetada pelas deformações novas. 


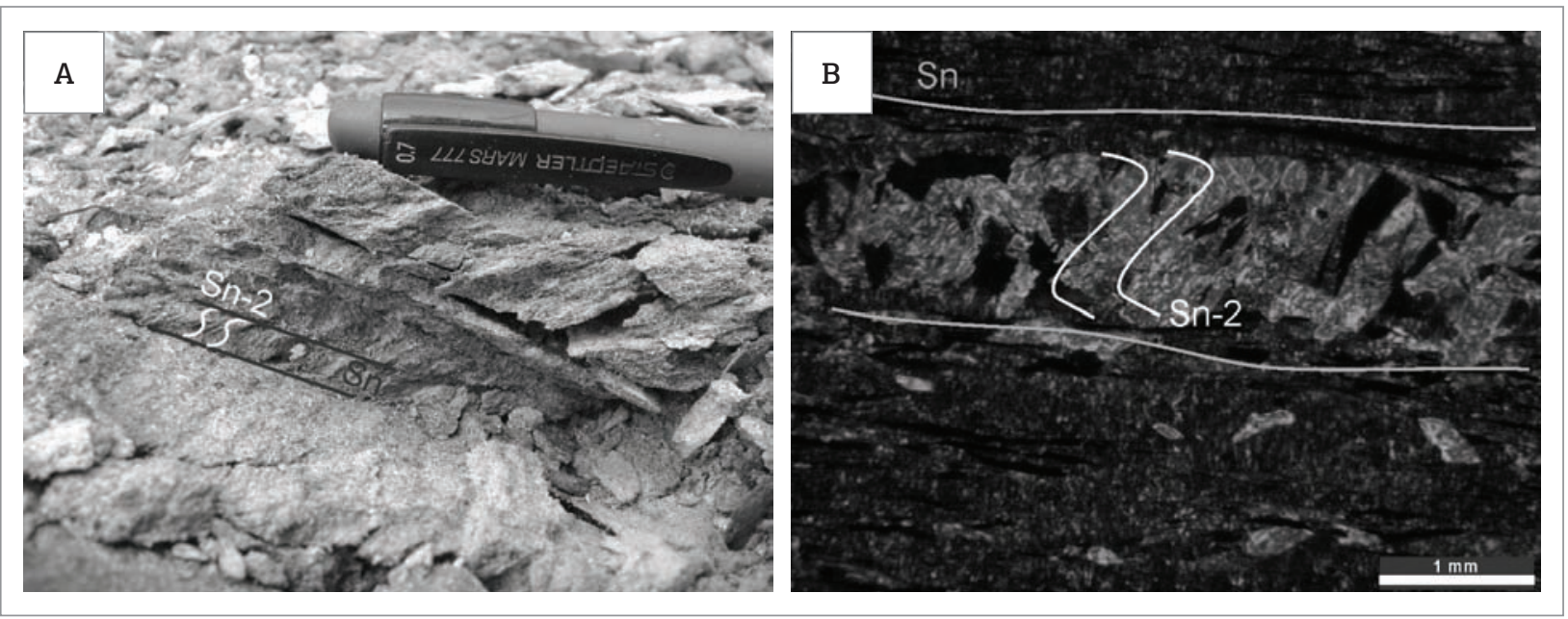

Figura 7. (A) Afloramento de quartzo-clorita-muscovita xisto com magnetita da Formação Aimbé UTM (644356, 8360196). $S_{n-2}$ marcada por mica e está sendo crenulado pela foliação $S_{n}$. As atitudes de $S_{n-2}$ e $S_{n}$ são, respectivamente, $72 / 35$ e 172/30. (B) Fotomicrografia de clorita-quartzo-muscovita xisto da unidade Araxá. $S_{n-2}$ preservada na foliação $S_{n}$ através de arcos poligonais de muscovita.

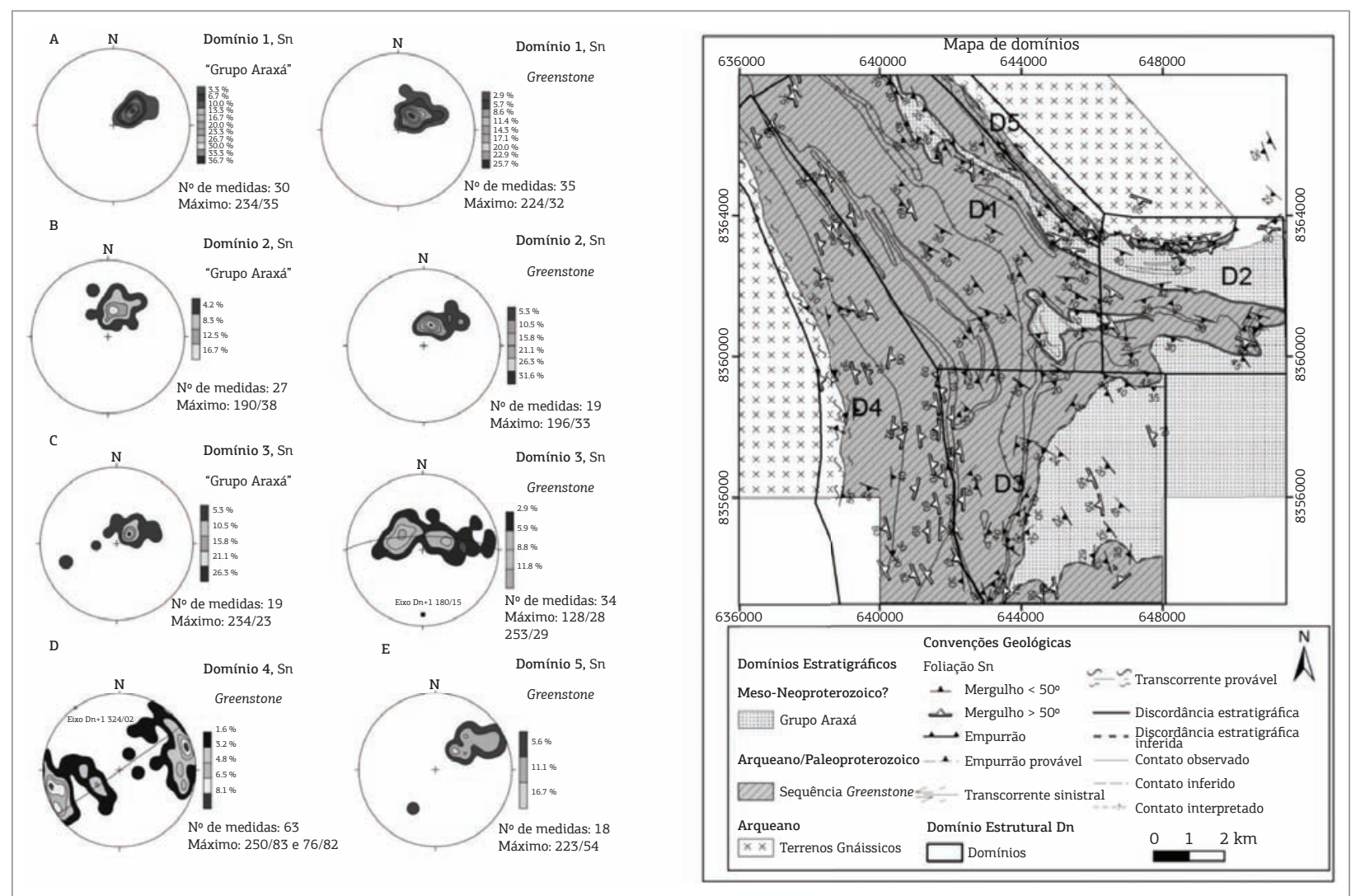

Figura 8. Diagramas estereográficos mostrando as orientações preferências de $S_{n}$ nos diferentes domínios ilustrados no mapa ao lado. Rede erquiárea, hemisfério inferior. 
No Domínio 1 revelam duas concentraçóes de medidas, uma (down dip) marcada por anfibólio e muscovita com atitude preferencial de 229/27, e outra direcional, definida por cristais de quartzo e lamelas de muscovita com atitude 144/07.

No domínio 1, os eixos de dobras $\mathrm{D}_{\mathrm{n}}$ possuem caimento subhorizontal para NW e SE. Nos quartzitos do "Grupo Araxá”, na Serra Maria Lázara, as dobras dessa fase são bem evidentes e se caracterizam por serem dominantemente apertadas, com ângulos interflancos menores que 30 graus.

No domínio 2, as dobras são semelhantes às descritas no domínio 1, com eixos de dobras paralelos à lineação de intersecção $\left(\mathrm{S}_{0} / / \mathrm{S}_{\mathrm{n}-2}\right.$ e $\left.\mathrm{S}_{\mathrm{n}}\right)$, atitude preferencial 98/09 e 280/07 e plano axial mergulhando para sul. Assim as estruturas mesoscópicas Dn das duas unidades são idênticas.

$\mathrm{S}_{\mathrm{n}}$ no domínio 3 possui atitudes variadas evidenciando a presença de dobras $\mathrm{D}_{\mathrm{n}+1}$, como pode ser visto nos estereogramas da Fig. 8C. Essa deformação de $S_{n}$ gera dobras com comprimentos de onda decimétricos a quilométricos, sendo estas dobras mais apertadas na porção ocidental deste domínio, sugerindo deformação mais intensa para W. Essas dobras afetam tanto a sequência greenstone belt como os metassedimentos do Grupo Araxá (Figs. 9C e 9D) apresentando semelhança geométrica e morfológica nas duas unidades.

Ao longo do domínio 4, encontram-se dobras apertadas afetando Sn, que apresenta atitudes preferenciais de 282/77 e 77/82, na porção sul, e 251/77 e 75/80, na porção norte. Embora o estereograma da Fig. 8D do greenstone inclua atitudes tanto norte como do sul. Através dessas medidas, a direção geral do eixo $\mathrm{D}_{\mathrm{n}+1}$ no domínio 4 possui atitude de 324/02, sugerindo uma maior influência das medidas da porção norte desse domínio.

No domínio 5, rochas do GBG estão em contato com os gnaisses do Moquém através da Zona de Cisalhamento
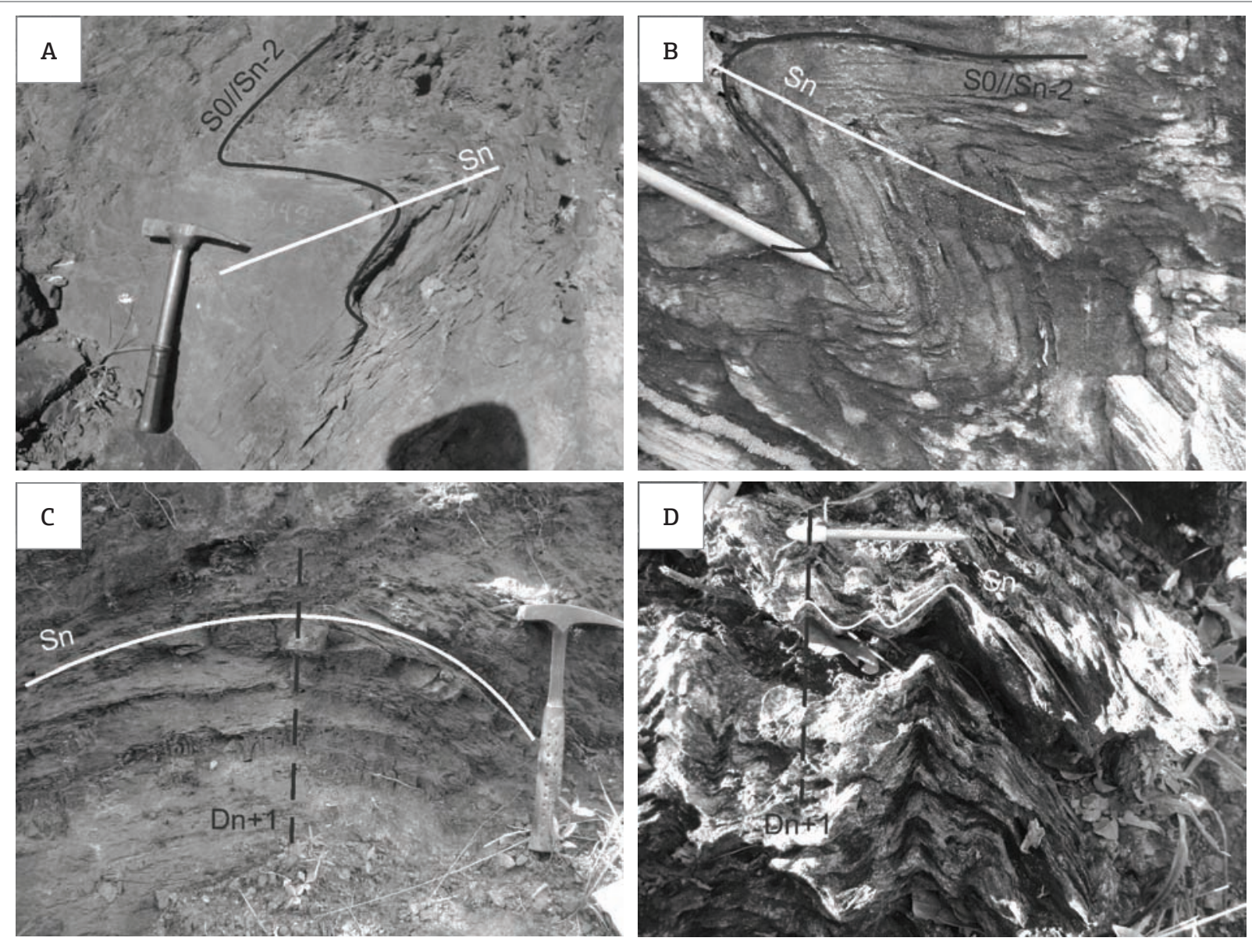

Figura 9. (A) Afloramento de gondito da Ca-2 no domínio 1 UTM $(646791,8361878)$. Dobra $D_{n}$ com a foliação $S_{n}$ plano axial, observada no domínio 1, com assimetria em S (olhando para norte). Atitude de $\mathrm{S}_{\mathrm{n}}$ e do eixo $\mathrm{D}$ são, respectivamente, 210/30 e 278/20. (B) Afloramento de quartzito micáceo da unidade Araxá UTM $(645499,8363430)$. Dobra $D_{n}$ com foliação $S_{n}$ plano axial. As atitudes do plano e eixo são, respectivamente, 230/35 e 270/28. (C) Afloramento de xisto carbonoso da Ca-3 da Formação Cabaçal UTM (644318, 8359447). $S_{n}$ é afetada por $D_{n+1}$, o eixo e o plano axial dessa deformação são, respectivamente, 170/10 e 90/80. (D) Afloramento de muscovita-quartzo xisto do Araxá UTM (647658, 8362487). $S_{n}$ é afetada por $D_{n+1}$, o eixo e o plano axial são, respectivamente, 178/07 e 260/82. 
Carroça $\left(\mathrm{D}_{\mathrm{n}+1}\right)$. No GBG, Sn é marcada por cristais de muscovita, anfibólio, biotita, clorita e grafita, com atitude de 223/54, quando próximo da Zona de Cisalhamento, Sn se torna verticalizada devido à componente deformacional de caráter dúctil. Na Zona de Cisalhamento Carroça a foliação nos gnaisses também está verticalizada com orientação de cristais de muscovita, biotita, quartzo e feldspato. O gnaisse expóe feições miloníticas evidenciadas por porfiroclastos de feldspato com franjas de recristalização assimétricas, em escala microscópica, cristais de muscovita apresentam forma alongada em losango indicando a formação de "mica fish". As lineações de estiramento/mineral são sub-horizontais com orientação preferencial 146/12, ora mergulhando para o lado oposto (N320). Os porfiroclastos de feldspato com franjas de recristalização assimétricas indicam movimento sinistral. Com a verticalização da foliação Sn do greenstone belt próximo a falha, entende-se que está deformação dúctil é, também, da fase $\mathrm{D}_{\mathrm{n}+1}$.

\section{Fases Pós- $\mathrm{D}_{\mathrm{n}}$}

As fases $\mathrm{D}_{\mathrm{n}+1}$ e $\mathrm{D}_{\mathrm{n}+2}$ afetam $\mathrm{Sn}$ gerando estruturas como dobras, foliaçáo plano axial, lineação de crenulação, e por vezes falhas. As estruturas relacionadas à $\mathrm{D}_{\mathrm{n}+1}$ ocorrem com maior frequência e são mais perceptíveis nos afloramentos, ao contrário de $\mathrm{D}_{\mathrm{n}+2}$, que é identificada por dobras, com baixa frequência e exposição, e lineação de crenulação vista localmente.

A fase $\mathrm{D}_{\mathrm{n}+1}$ gera dobras de comprimentos de onda centimétricos a quilométricos, localmente com clivagem de crenulação $\left(S_{n+1}\right)$ desenvolvida paralelamente aos planos axiais das dobras dessa fase. $S_{n+1}$ ocorre com frequência nas rochas das Formaçôes Serra do Cotovelo e Serra Azul, enquanto as dobras com comprimento de onda centimétrico a quilométrico de morfologia aberta e suave são comuns no domínio 1, 2 e 3. Nos quartzitos da Serra Maria Lázara identifica-se superposição de dobras $\mathrm{D}_{\mathrm{n}+1}$ sobre dobras $\mathrm{D}_{\mathrm{n}}$, onde o plano axial das dobras $\mathrm{D}_{\mathrm{n}}$ é dobrado por $\mathrm{D}_{\mathrm{n}+1}$ gerando dobras abertas (Fig. 10A).

As crenulaçóes em $S_{n}$, por vezes apertadas e numerosas, são simétricas a assimétricas, ocorrendo preferencialmente nos mica xistos da porção leste, litotipos do "Grupo Araxá".

Em geral estas dobras não apresentam foliação plano-axial; entretanto, em alguns locais, como por exemplo no Domínio 4, a crenulaçáo $\mathrm{D}_{\mathrm{n}+1}$ é mais forte e desenvolve foliação plano axial. Na porção norte do domínio 4, $S_{n}$ e $S_{n+1}$ são dificilmente diferenciáveis, principalmente na porção oeste, pois ocorrem de forma subparalela. A orientação preferencial da foliação de $S_{n+1}$ e dos planos axiais dessas dobras apresenta atitude 262/81. Paralelo ao eixo das dobras $\mathrm{D}_{\mathrm{n}+1}$ ocorre uma lineação de crenulação (Lc) com atitude preferencial de 170/10.

A Falha Azul (Fig. 3), interpretada como fase $\mathrm{D}_{\mathrm{n}+1}$, expóe os contatos das camadas das formaçóes Sáo Patricinho, Aimbé e Cabaçal, subunidade Ca-4, truncados nos litotipos da Formaçáo Serra Azul.

Também relacionamos a este evento deformacional a Zona de Cisalhamento Carroça, com direçâo NW-SE que abrange uma faixa de aproximadamente $150 \mathrm{~m}$ de largura por aproximadamente 10 quilômetros de comprimento. As rochas no interior da zona apresentam granulação fina, foliação milonítica, com alto ângulo de mergulho, por vezes verticalizada, e com direção N310. Fora da abrangência da zona de cisalhamento, a textura da foliação milonítica no gnaisse do Moquém é média a grossa, com direção também de N310, porém com ângulos de mergulho menores,

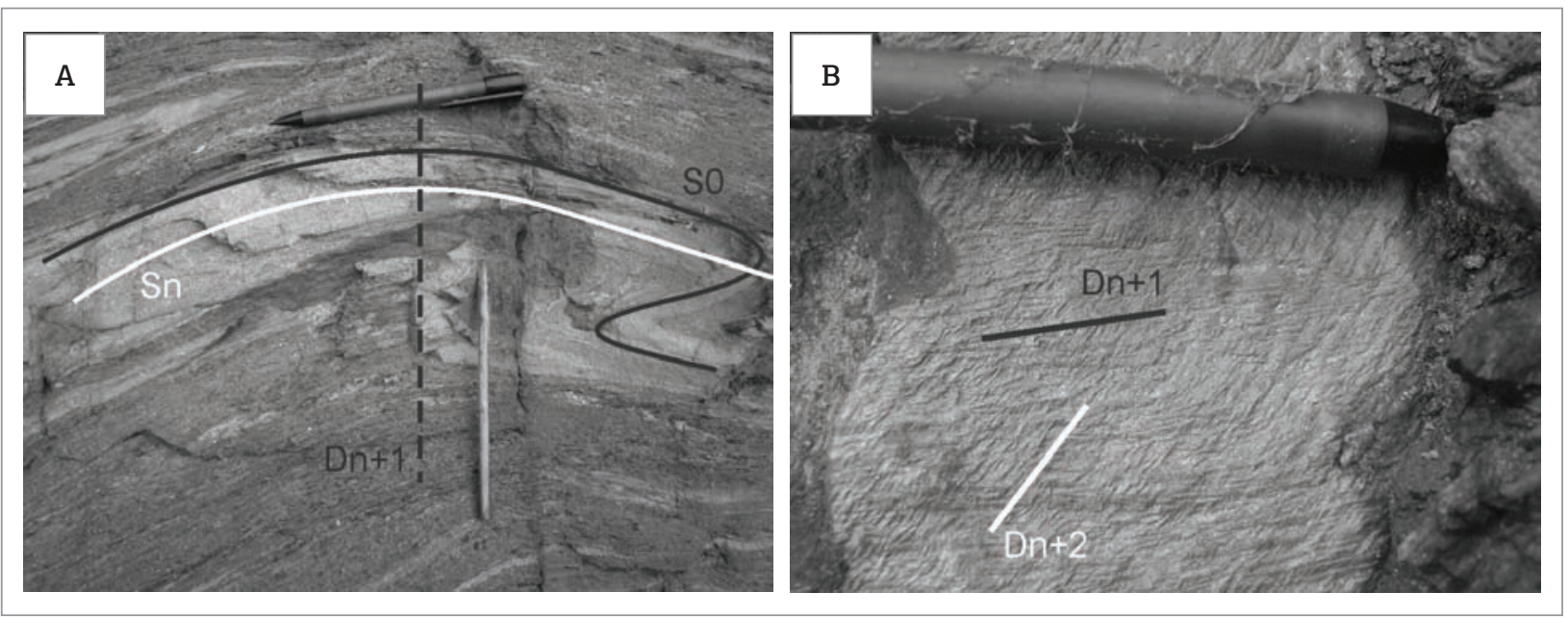

Figura 10. (A) Afloramento de clorita-muscovita-quartzo xisto do "Grupo Araxá". Dobra $\mathrm{D}_{\mathrm{n}}$ com plano axial paralelo à foliação $S_{n}$, sendo dobrada pela fase $D_{n+1}$ UTM $(645699,8363231)$. (B) Afloramento de xisto carbonoso da subunidade Ca-3 UTM $(642675,8360626)$. As lineações de crenulação aparecem no plano da foliação $S_{n}$ e as atitudes dessas estruturas lineares da fase $D_{n+1}$ e $D n+2$ são respectivamente 175/10 e 220/30. 
50 - 60 graus. Na porção leste da área, a falha com direção NW-SE sofre inflexão para E, e a foliação nesta localidade apresenta textura grossa, pouco milonítica, com direção E-W e mergulho de 50 graus para sul.

A fase $\mathrm{D}_{\mathrm{n}+2}$ gera dobras abertas e lineaçóes de crenulaçóes afetando a foliação $S_{n}$. Os eixos das dobras e as lineaçóes de crenulação possuem atitude preferencial 220/30 (Fig. 10B). As dobras apresentam planos axiais de direção NE a ENE e mergulho vertical a subvertical, que contrasta com a direção preferencial dos planos axiais $\mathrm{D}_{\mathrm{n}+1}$, que é NW. Esta direção dos eixos $\mathrm{D}_{\mathrm{n}+2}$ implica em um encurtamento aproximadamente NW-SE; por isso, interpreta-se que a inflexão do greenstone de Guarinos na porção W da área, que é acompanhada da curvatura da foliação $\mathrm{Sn}$ no domínio 4 , do plano axial $\mathrm{D}_{\mathrm{n}+1}$ e também na alternância do mergulho do eixo $\mathrm{D}_{\mathrm{n}+1}$ apresentando duplo caimento, seja causada por $\mathrm{D}_{\mathrm{n}+2}$.

Em afloramentos, não se observou claramente a relação de corte das estruturas $\mathrm{D}_{\mathrm{n}+2} \operatorname{com}$ as da fase $\mathrm{D}_{\mathrm{n}+1}$.

\section{METAMORFISMO E SUAS RELAÇÕES COM AS MICROESTRUTURAS}

As paragêneses predominantemente marcam o auge do metamorfismo da região e são atribuídas ao metamorfismo principal (MP). Também são encontrados minerais neoformardos indicando re-equilíbrio em baixa temperatura, que são relacionados ao evento retrometamórfico (RM).

As paragêneses mineralógicas do MP que afetou tanto o greenstone quanto as rochas do "Grupo Araxá", correspondem às condiçóes da zona da granada da fácies xisto verde.

$\mathrm{O}$ auge metamórfico durante o evento deformacional $\mathrm{D}_{\mathrm{n}}$ gerou porfiroblastos cuja relação textural com a foliação $S_{n}$ indica crescimento contemporâneo ao estágio final de $\mathrm{D}_{\mathrm{n}}$. A idade para o auge metamórfico é ainda incerta, necessitando de um método específico para datação.

O retrometamorfismo nos gnaisses para fácies xisto verde é identificado pela saussuritização do plagioclásio e feições de microestruturas nos cristais de quartzo e plagioclásio que indicam baixas temperaturas. Essas microestruturas são evidenciadas através da extinção ondulante no quartzo e pela recristalização restrita à borda dos grãos (bulging - Passchier \& Trouw, 2005) de plagioclásio, onde forma-se uma protuberância no cristal menos deformando que cresce às custas do mais deformado. Nos metassedimentos do "Grupo Araxá" alguns cristais de clorita correspondem a pseudoformos de biotita, indicando também o efeito de retrometamorfismo.

As rochas da Formação Serra Azul apresentam no MP assembleia de actinolita + epidoto + clorita \pm albita \pm quartzo \pm tremolita \pm hornblenda (porção norte). O aparecimento de actinolita + epidoto na presença de clorita diagnostica início de fácies xisto verde e pode ser formando ao redor de $280^{\circ} \mathrm{C}$ (Bucher \& Frey 1994). A ocorrência de finas bordas de hornblenda na actinolita em algumas lâminas sugere condiçôes mais elevadas no metamorfismo. Segundo Yardley (2004), rochas metabásicas na fácies xisto verde com actinolita \pm epidoto \pm albita \pm clorita \pm estilpnomelano correspondem a zona de temperatura mais baixa, já as associaçóes minerais relacionadas a zona de temperatura mais elevadas são marcadas pela presença de hornblenda \pm actinolita \pm albita \pm clorita \pm epidoto \pm granada. A assembleia citada, principalmente pela presença de hornblenda e albita, indica que as condições de equilíbrio correspondem às da fácies xisto verde superior.

Nos metapelitos do "Grupo Araxá" são identificados muscovita, quartzo, biotita, clorita, plagioclásio (albita principalmente) e granada (almandina). Na porção norte a assembleia mineralógica dos metassedimentos compreende essencialmente granada (almandina), quartzo, muscovita, biotita, clorita e opacos, já a sul e a leste a granada é ausente. Assim, a presença de granada nos metassedimentos do Grupo Araxá na porção norte evidencia aumento do grau metamórfico. $\mathrm{Na}$ porção mais a norte, fora da área mapeada, observou-se em lâminas petrográficas paragênese hornblenda + oligoclásio nos metassedimentos da subunidade $\mathrm{Ca}-2$. A presença desses minerais indica início de fácies anfibolito, que ocorre em temperaturas ao redor de $500^{\circ} \mathrm{C}$ (Bucher \& Frey 1994). Essas observaçóes sugerem a existência de gradiente metamórfico com aumento progressivo de temperatura para norte.

Porfiroblastos crescidos em diferentes ângulos com a foliação Sn em rochas do "Grupo Araxá", mostram cristalização tardi- $\mathrm{D}_{\mathrm{n}}$. Feição similar ocorre nas rochas da Formação Aimbé, onde a muscovita apresenta recristalização pós $D_{n}$.

\section{CONCLUSÃO}

Os contatos litológicos da sequência greenstone belt $\mathrm{e}$ dos metassedimentos do "Grupo Araxá" evidenciam truncamentos de difícil entendimento, sugerindo assim períodos distintos de sedimentação, além de diversas fases deformacionais que também contribuíram para geração de novos e reestruturação desses truncamentos.

$\mathrm{Na}$ área estudada, as unidades metavulcânicas (formaçôes Serra do Cotovelo e Serra Azul) fazem contato tectônico com a sequência com predomínio metassedimentar, impossibilitando avaliar a relação estratigráfica entre estes dois conjuntos. Adotou-se a proposta da literatura que indica as sequências vulcânicas na porção basal do greenstone. Na sequência metassedimentar, o empilhamento encontrado inicia-se pela unidade A (informalmente definida neste trabalho), seguida por quatro subunidades da Formação Cabaçal (Ca-1, Ca-2, 
Ca-3 e Ca-4), passando à Formação Aimbé, e, no topo do pacote, a Formação São Patricinho. Identificou-se o truncamento das subunidades da Formação Cabaçal pela Formação Aimbé, que pode representar uma discordância ou uma descontinuidade tectônica precoce.

Não foram identificadas estruturas primárias que mostrem claramente a polaridade estratigráfica do pacote. Assim, embora não se possa excluir a possibilidade de inversão tectônica proposta na literatura, entende-se que a posição normal do empilhamento encontrado é uma alternativa viável para a área.

O contato das rochas do Greenstone Belt de Guarinos com os metassedimentos do "Grupo Araxá" mostram tendência para uma discordância estratigráfica, devido à ausência de textura milonítica típica e/ou de equivalentes de caráter rúptil, como brechação. Porém não se pode descartar a hipótese de que tenha havido uma superfície de cavalgamento cujas feiçôes miloníticas tenham sido apagadas pela recristalização tardi- $\mathrm{D}_{\mathrm{n}}$ sofrida por essas rochas. $\mathrm{O}$ que se observa nitidamente em lâminas petrográficas das amostras próximas ao contato é uma recristalização tardia que afeta igualmente todo conjunto do greenstone e os litotipos do "Grupo Araxá".
Foram identificadas cinco fases deformacionais, duas mais antigas $\left(D_{n-2}\right.$ e $\left.D_{n-1}\right)$, a fase principal $\left(D_{n}\right)$ e duas mais novas $\left(D_{n+1}\right.$ e $\left.D_{n+2}\right)$ que afetam a foliação $S_{n}$.

A foliação tectônica $S_{n}$ é a feição de maior expressão encontrada nas rochas do greenstone belt e nos metassedimentos pelíticos do "Grupo Araxă". A orientação de $S_{n}$ nessas unidades varia ao longo da área, porém as atitudes preferenciais em cada domínio se comporta de forma uniforme, evidenciando que esta deformação afetou igualmente todo o conjunto de rochas.

\section{AGRADECIMENTOS}

Este trabalho foi apoiado pelo Conselho Nacional de Desenvolvimento Científico e Tecnológico (CNPq Processo 133347/2010-9). Os autores agradecem à Yamana Desenvolvimento Mineral S.A. pelo acesso aos dados de mapeamento geológico de detalhe e regional. Agradecimentos são extensivos ao Professor Dr. Luiz Sérgio Amarante Simóes pela sua participação nos trabalhos de campo e valiosas discussóes ao longo deste trabalho.

\section{REFERÊNCIAS}

Bucher K. \& Frey M. (eds). 1994. Petrogenesis of metamorphic rocks. Heidelberg, Springer-Velag, 318 p.

Castro J.H.G. \& Magalhães L.F. 1984. Revisão estratigráfica do Grupo Pilar de Goiás na Faixa Crixás. In: SBG, $33^{\circ}$ Congresso Brasileiro de Geologia, Rio de Janeiro, Anais, v. 6, p. 2563-2576.

Danni J.C.M. 1988. Os Greenstone Belts da Província Tocantins no Estado de Goiás, Brasil. Revista Brasileira de Geociências, 18(4):381-390

Danni J.C.M. \& Ribeiro C.C. 1978. Caracterização da sequência vulcano sedimentar de Pilar de Goiás e Guarinos. In: SBG, 30 Congresso Brasileiro de Geologia, Recife, Anais, v. 2, p. 582-596.

Jost H., Dussin I.A., Chemale F.J., Tassinari C.C.G., Junges S. 2008. $\mathrm{U}-\mathrm{Pb}$ and $\mathrm{Sm}-\mathrm{Nd}$ constraints for the Paleoproterozoic age of the metasedimentary sequences of the Goiás Archean greenstone belts. In: $6^{\circ}$ South American Symposium on Isotope Geology, San Carlos de Bariloche, p. 1-4.

Jost H. \& Fortes P.T.F.O. 2001. Gold deposits and occurrences of the Crixás Goldfield, central Brazil. Mineralium Deposita, 36:358-376.

Jost H., Kuyumjian R.M., Freitas A.L.S., Costa A.L.L., Nascimento C.T.C., Vasconcelos F.M., Galotti Neto L., Martins M.C., Carvalho M.N., Condé V.C. 1995. Geologia da porção norte do greenstone belt de Guarinos, Goiás. Revista Brasileira de Geociências, 25(1):51-60.

Jost H. \& Oliveira A. 1991. Stratigraphy of the greenstone belts, Crixás region, Goiás, central Brazil. Journal of South American Earth Sciences, 4:201-214.

Jost H., Rodrigues V.G., de Carvalho M.J., Farid Junior F.C., Marques J.C. 2012. Estratigrafia e geocronologia do greenstone belt de Guarinos. Geologia USP - Série Científica, 12(2):31-48.

Kretz R. 1983. Symbols for rock-forming minerals. American Mineralogist, 68:277-279.
Lacerda H. 1997. Mapa Geológico 1/100.000 do Distrito Mineiro do Greenstone Belt de Crixás-Guarinos-Pilar de Goias (GO): Versão Preliminar. In: SBG, 60 Simpósio de Geologia do Centro-Oeste, Anais, p. 65-67.

Lacerda FilhoJ.V.\&Frasca A.A.S. 2008. Proposta de compartimentação geotectônica do estado de Goiás e Distrito Federal. In: SBG, $44^{\circ}$ Congresso Brasileiro de Geologia, Anais, v. 1, p.26-31.

Passchier C.W. \& Trouw R. (eds.). 2005. Micro-tectonics. 2. ed. Berlin, Springer, $289 \mathrm{p}$.

Pulz G.M. 1995. Modelos prospectivos para ouro em greenstone belts: exemplo dos depósitos Maria Lázara e Ogó, na região de Guarinos e Pilar de Goiás, Goiás. PhD Thesis, Instituto de Geociências, Universidade de Brasília, Brasília, 189 p.

Queiroz C.L. 2000. Evolução tectono-estrutural dos terrenos granitogreenstone belt de Crixás, Brasil Central. PhD Thesis, Instituto de Geociências, Universidade de Brasília, Brasília, 209 p.

Queiroz C.L., McNaughton N.J., Fletcher I.R., Jost H., Barley M.E. 2000. Polymetamorphic history of the Crixás-Açu Gneisses, Central Brazil: SHRIMP U-Pb evidence from titanite and zircon. Revista Brasileira de Geociências, 30(1):40-44.

Resende M.G. \& Jost H. 1995. Petrogênese de formações ferríferas e metahidrotermalitos da Formação Aimbé, Grupo Guarinos (Arqueano), Goiás. Revista Brasileira Geociências, 25(1):41-50.

Ribeiro Filho W. 1981. Reavaliação da geologia de Pilar-Mara Rosa. In: SBG, $1^{\circ}$ Simpósio de Geologia do Centro-Oeste, Atas, p. 281-299.

Sabóia L.A. 1979. Os greenstone belts de Crixás e Goiás, GO. In: SBG, Núcleo Centro-Oeste, Boletim Informativo, 9:44-72.

Yardley B.W.D. (ed.). 2004. Introdução à petrologia metamórfica. Brasília, Editora da Universidade de Brasília, 434 p.

Arquivo digital disponível on-line no site www.sbgeo.org.br 